Article

\title{
Extensive Structure Modification on Luteolin-Cinnamic Acid Conjugates Leading to BACE1 Inhibitors with Optimal Pharmacological Properties
}

\author{
De-Yang Sun ${ }^{1}$, Chen Cheng ${ }^{2}$, Katrin Moschke ${ }^{3,4}$, Jian Huang ${ }^{2}$ and Wei-Shuo Fang ${ }^{1, *}$ \\ 1 State Key Laboratory of Bioactive Substances and Functions of Natural Medicines, Institute of Materia \\ Medica, Chinese Academy of Medical Sciences and Peking Union Medical College, 2A Nan Wei Road, \\ Beijing 100050, China; sdy887@126.com \\ 2 College of Life Science, Wuhan University, Wuhan 430072, Hubei, China; cccc@whu.edu.cn (C.C.); \\ jianhuang@whu.edu.cn (J.H.) \\ 3 German Center for Neurodegenerative Diseases (DZNE) and Munich Cluster for Systems \\ Neurology (SyNergy), Technical University of Munich, Feodor-Lynen-Strasse 17, 81377 Munich, Germany; \\ katrin.moschke@dzne.de \\ 4 Neuroproteomics, Klinikum rechts der Isar, Technical University of Munich, 81675 Munich, Germany \\ * Correspondence: wfang@imm.ac.cn; Tel.: +86-10-6316-5229
}

Academic Editors: Kamil Kuca, Tanos Celmar Costa Franca and Teodorico C. Ramalho Received: 21 November 2019; Accepted: 23 December 2019; Published: 26 December 2019

\begin{abstract}
BACE1 inhibitory conjugates derived from two natural products, luteolin (1) and $p$-hydroxy-cinnamic acid (2), were subjected to systematic structure modifications, including various positions in luteolin segment for conjugation, different linkers (length, bond variation), as well as various substitutions in cinnamic acid segment (various substituents on benzene, and replacement of benzene by heteroaromatics and cycloalkane). Optimal conjugates such as $\mathbf{7 c}$ and $\mathbf{7 k}$ were chosen on the basis of a series of bioassay data for further investigation.
\end{abstract}

Keywords: beta-secretase; BACE1 inhibitor; flavonoid; luteolin; cinnamic acid

\section{Introduction}

Alzheimer's disease (AD) is an age-dependent chronic neurodegenerative disease that is characterized by the presence of extracellular senile plaques and neurofibrillary tangles, as well as synaptic dysfunction and neuronal cell death. According to the World Health Organization (WHO), about 35.6 million people were diagnosed with dementia in 2010, and the number is projected to double every 20 years. The overall cost for dementia worldwide has been estimated at approximately 604 billion U.S. dollars [1].

Although the cause of AD remains in debate, $\beta$-amyloid cascade hypothesis (A $\beta$ hypothesis) or its modified version is the most widely accepted pathological mechanism according to genetic and pathological evidence among many mechanisms. A $\beta$, a peptide consisting of 37-43 amino acids, is proposed as aggregating into soluble oligomers and fibrils, which are toxic to neurons, causing neuronal death. Another protein, tau, can also be a causative factor independently, presumably acting downstream of $A \beta$ aggregation [2-4].

$A \beta$ is generated by the sequential endoproteolytic cleavage of amyloid precursor protein (APP), a transmembrane protein expressed in many tissues and organs, by $\beta$-secretase (BACE1, also known as $\beta$-site amyloid precursor protein cleaving enzyme 1) and $\gamma$-secretases subsequently in the brain [5]. 
Thus, the key enzyme BACE1 involved in the generation of $A \beta$ has been regarded as an attractive AD drug target for about two decades. Many different chemotypes of BACE1 inhibitors have been developed [6]. Although some BACE1 inhibitors have advanced to clinical research, none of them have finished the phase III clinical trial due to diverse side effects and/or lack of effectiveness [7].

The failure of these clinical trials, including the most recent discontinuation of AstraZeneca/Eli Lilly's Lanabecestat in phase III clinical trial, proposed that the early intervention of AD, even without any symptoms, may be necessary for the success of the BACE1 inhibitors [8,9]. The kickoff of prevention trial with BACE1 inhibitor CNP250 represents a new trend in BACE1 inhibitor development [10].

The side effects have arisen from, at least for some of the BACE1 inhibitor drug candidates, the indiscriminately blocking of almost all functions and substrate cleavages related to BACE1 by the active site inhibitors [11].

Unlike competitive inhibitors targeting enzyme active site, non-competitive inhibitors binding to allosteric sites may selectively inhibit specific functions of an enzyme, resulting in less side effects [12].

In our previous work [13], luteolin (1) and $p$-hydroxy-cinnamic acid (2) (Figure 1) were found to simultaneously bind different parts of BACE1 protein by STD-NMR experiment [14]. We designed the conjugates to link two segments through proper linkage to improve the potency. Conjugate 3 (Figure 1) was found in our previous work as a potent, cell-permeable, and non-competitive inhibitor. In this work, an extensive modification of 3 was designed and performed to optimize it so as to find BACE inhibitors with optimal drug-like properties.

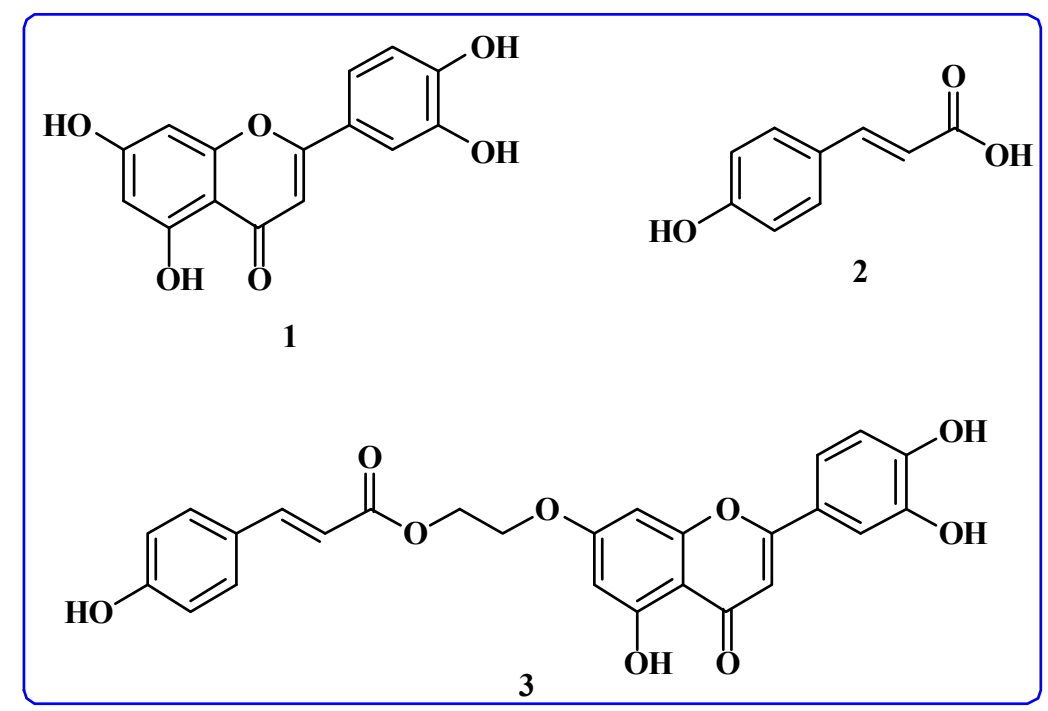

Figure 1. The structures of source compounds 1, 2, and 3.

In this paper, we first probed the different positions in flavonoid segment for conjugation of cinnamoyl segment, in order to avoid the possibly imprecise information derived from STD-NMR. After the C-7 position of flavone segment was confirmed as the optimal position among all conjugates in Series I, we further designed and prepared Series II and Series III compounds to optimize the linker and substituents in the cinnamoyl segment of the conjugate (Figure 2). 


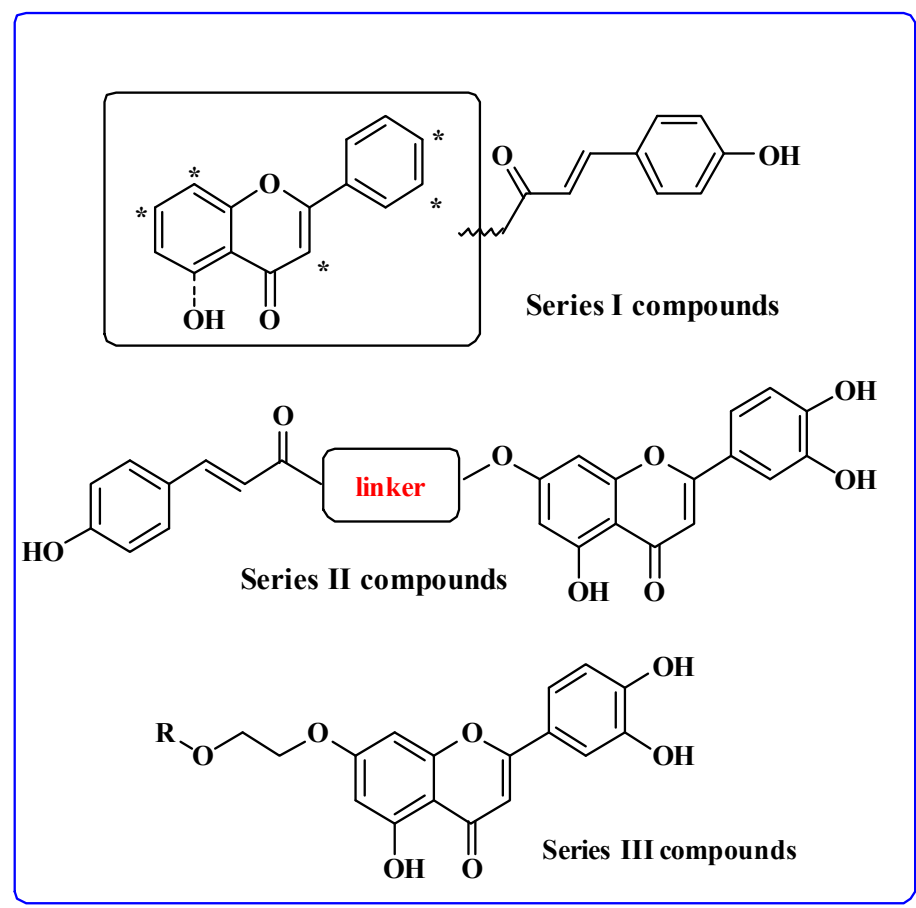

Figure 2. The structures of Series I, II, III compounds.

\section{Results and Discussion}

\subsection{Design, Synthesis, and Enzyme Inhibitory Activity of Series I Compounds}

Although in our previous work [13] a cell permeable BACE1 inhibitor 3 was discovered with the STD-NMR, we wished in this study to probe various positions in $\mathbf{1}$ (including $3^{\prime}, 4^{\prime}, 3,6$, and 8 positions) for direct conjugation of 2 or through ethylene glycol linkers, to avoid the possibly misleading of imprecise STD-NMR data.

In general, our designed conjugates consisted of a flavone segment, a linker, and a cinnamoyl segment. However, the synthetic routes and the choice of starting material varied to a great extent for the different conjugates.

Most luteolin analogs with hydroxyl at different positions as the flavone segment for conjugation are not commercially available, and thus were assembled from the simple starting materials aromatic aldehyde and aromatic ketone with different substituting groups, through condensation, to form chalcone structure under basic conditions, cyclized to dihydroflavone under heating conditions, and then oxidized to flavonoids with $\mathrm{I}_{2}$ /pyridine under heating conditions (Scheme 1 and Supplementary Materials).

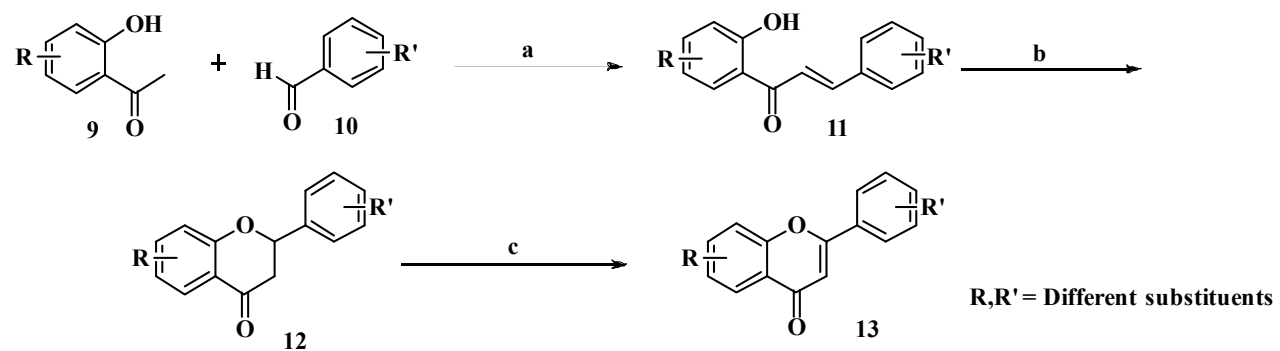

Scheme 1. The key synthetic steps of flavonoid structure. Reagents and conditions: (a) $20 \% \mathrm{KOH}$ aq. ethanol, room temperature, 52-69\%; (b) NaOAc, $\mathrm{H}_{2} \mathrm{O}$, ethanol, reflux, 26-82\%; (c) $\mathrm{I}_{2}$, pyridine, $100{ }^{\circ} \mathrm{C}$, $55-88 \%$. 
For the synthesis of conjugate $\mathbf{4 j}$, the flavone segment quercertin (3-OH substituted luteolin) was prepared by de-glycosylation of a natural compound rutin (auercetin-3-rutinoside). At first, per-benzylated rutin (14) was subjected to acid hydrolysis due to the poor stability of rutin under acidic condition. Then, ethylene glycol linker was attached to 3-OH to afford 17. The switch of benzyl-protecting groups in $\mathbf{1 7}$ to methoxymethyl group in combination of the removal of temperorary silyl protection of 3-O-ethylene-ol over two steps furnished 20, which was ready for the 3-O-conjugation of cinnamoyl side chain. The switch of protecting group was intended to avoid the stringent deprotection conditions at the final stage of target compound preparation (Scheme 2).

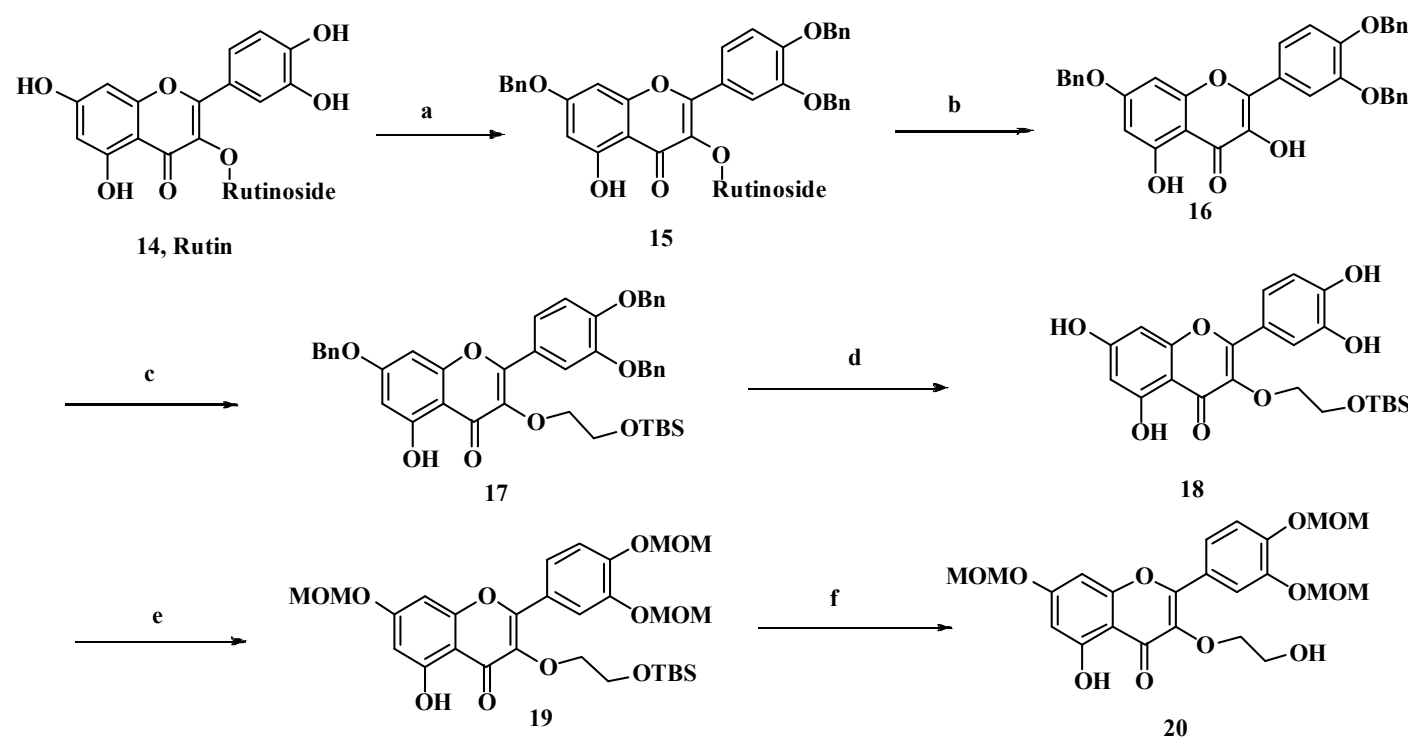

Scheme 2. The synthetic route of target $4 \mathbf{j}$ (1). Reagents and conditions: (a) BnBr, DMF, $50{ }^{\circ} \mathrm{C}$; (b) $\mathrm{HCl}, \mathrm{CH}_{3} \mathrm{CH}_{2} \mathrm{OH}, 70{ }^{\circ} \mathrm{C}, 84 \%$ (two steps); (c) $\mathrm{BrCH}_{2} \mathrm{CH}_{2} \mathrm{OTBS}, \mathrm{K}_{2} \mathrm{CO}_{3}, 80{ }^{\circ} \mathrm{C}, 53 \%$; (d) $\mathrm{Pd} / \mathrm{C}$, 1,4-cyclohexadiene, $80{ }^{\circ} \mathrm{C}$, $79 \%$; (e) MOMCl, DIPEA, DCM, $-20{ }^{\circ} \mathrm{C}, 57 \%$; (f) CsF, DMF, $50{ }^{\circ} \mathrm{C}, 83 \%$.

The terminal hydroxyl group in 20 was esterified with 4 "-acetyl cinnamic acid by activated ester method, and then the acetyl in $\mathbf{2 1}$ was successively removed under alkaline condition and MOM groups under acidic condition to afford desired conjugates $4 \mathbf{j}$ (Scheme 3).<smiles>COc1ccc(/C=C/C(=O)OCCOc2c(-c3ccc(OC)c(OC)c3)oc3cc(OC)cc(O)c3c2=O)cc1</smiles>

20<smiles>COc1cc(O)c2c(=O)c(OCCOC(=O)/C=C/c3ccc(O)cc3)c(-c3ccc(OC)c(OC)c3)oc2c1</smiles>

Scheme 3. The synthetic route of target $4 \mathbf{j}$ (2). Reagents and conditions: (g) 4"-acetyl cinnamic acid, EDCI, DMAP, TEA, THF, r.t. $45 \%$; (h) $\mathrm{K}_{2} \mathrm{CO}_{3}$ in $\mathrm{MeOH} / \mathrm{DCM}$, r.t. $56 \%$; (i) aq. $38 \% \mathrm{HCl}$ in $\mathrm{AcOH}(v / v$ $1: 15)$, r.t. $54 \%$

As seen from Table 1, the BACE1 inhibition of conjugates $4 \mathbf{a}-\mathbf{i}$ with $p$-hydroxy-cinnamic acid attached to $C-3^{\prime}$ and $-4^{\prime}$ of $\mathbf{1}$, no matter what the linker was, and was weaker than the conjugation to 
other positions of $\mathbf{1}$. Respectively, the inhibitory effect of conjugates $4 \mathbf{j}, \mathbf{4 k}$, and $\mathbf{4 1}$ attached to C-3, C-6, and C-8 were stronger than C-3' and $-4^{\prime}$ conjugates but weaker than the C-7 conjugate, 3 . Conjugate $4 \mathbf{k}$ was weaker than the flavone segment 1 (without conjugation of 2 ). The above results demonstrated the C-7 in flavone segment as the optimal conjugation position, consistent with optimization based on STD-NMR.

In addition, the acetyl group reduced inhibitory activity for all pairs of compounds (4a vs. $4 \mathbf{b}, 4 \mathbf{c}$ vs. $4 \mathrm{~d}, \mathbf{4 g}$ vs. $4 \mathrm{~h}$ ), suggesting the terminal phenol group may play a role in the enzyme inhibition.

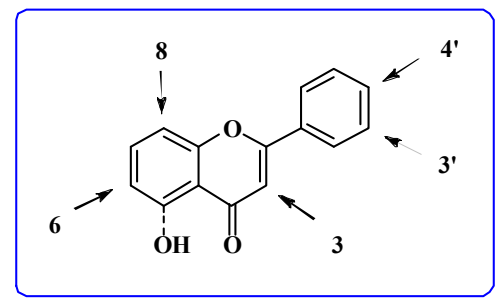

Table 1. The enzyme inhibition of Series I compounds.

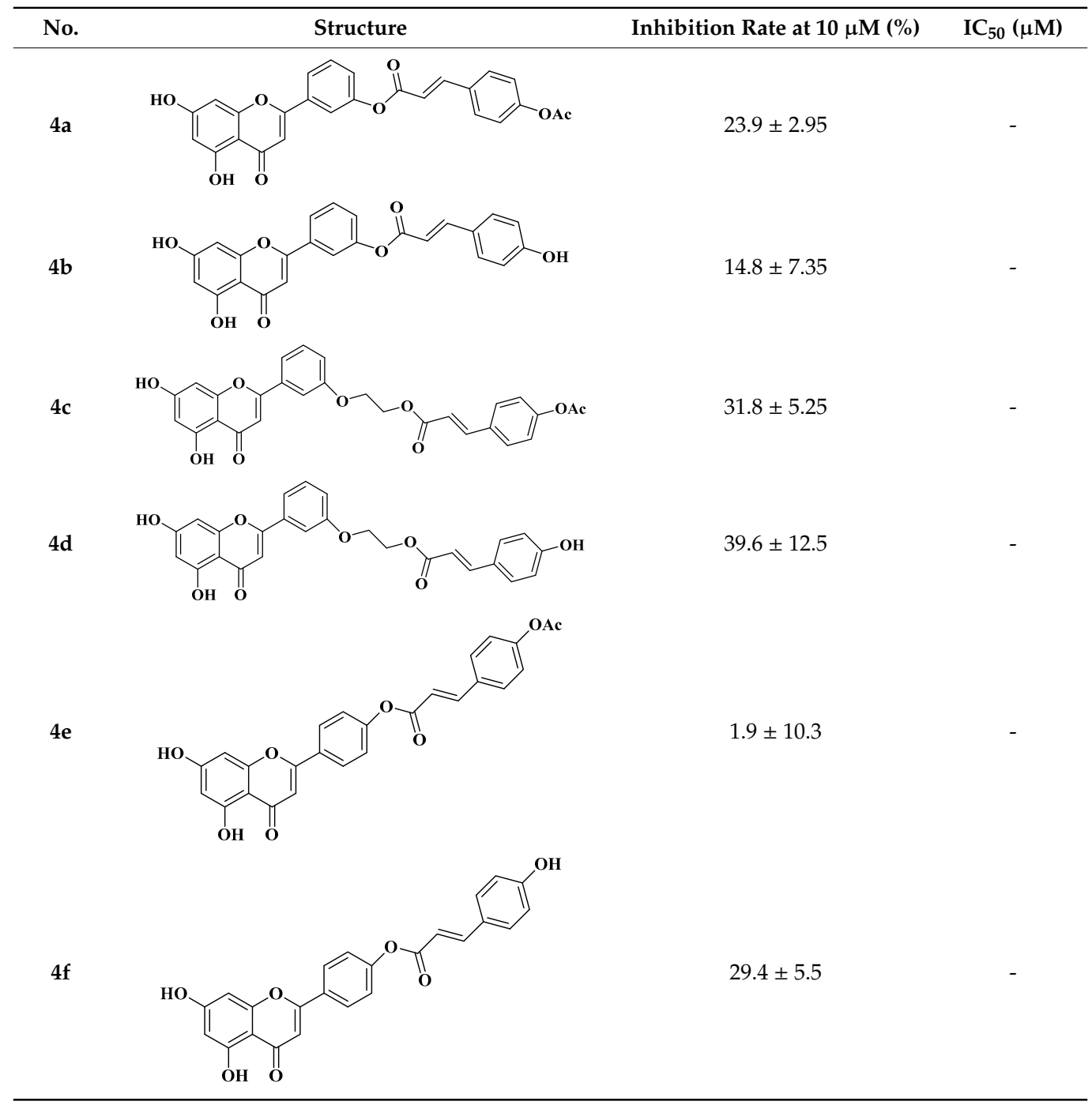


Table 1. Cont.

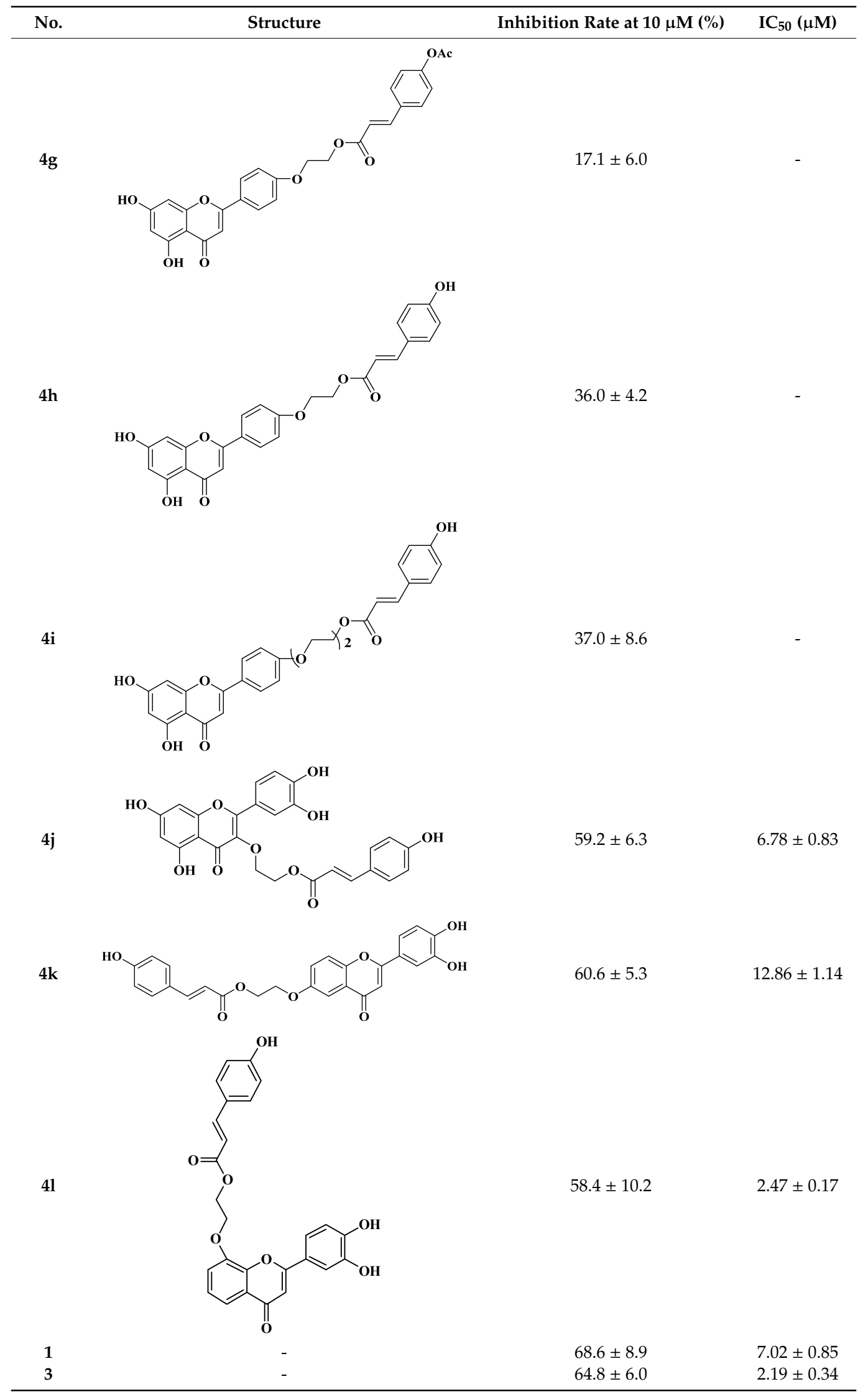




\subsection{Design, Synthesis, and Activity of Series II Compounds}

In the previous study [13], conjugates with one to four glycols units as linkers were tested, and compound with one glycol unit (i.e., in 3) was found to be the optimal. Here, we replaced glycol linkers by other polymethylene diols, trying to optimize the length of linker more carefully (Figure 3).

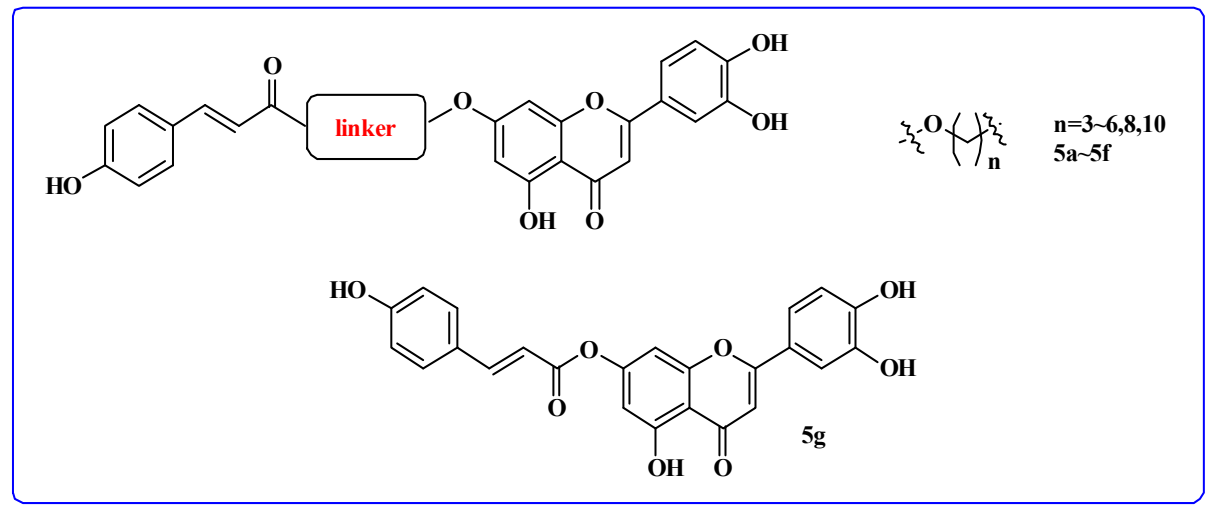

Figure 3. The design of Series II compounds.

For the synthesis of Series II compounds, the di-phenol groups on the $\mathrm{C}$ ring of $\mathbf{1}$ were protected with diphenylmethylidene to prepare 23 . The preparation of different hydroxyalkyl-7-luteolin could be realized by the treatment of $\mathbf{2 3}$ with TBS-O-hydroxyalkyl tosylate- under $\mathrm{K}_{2} \mathrm{CO}_{3}$ /acetone, except for butylene diol, in which case the reagent 4-hydroxybutyl 1-tosylate was subjected to intramolecular reaction to furnish tetrahydrofuran under the basic condition, possibly due to high reactivity of the OTs group. Thus, 4-TBS-O-butyl bromide was applied to this conjugation and the key intermediate $\mathbf{2 4}$ successfully prepared. After the removal of silyl protective group in 24, the terminal hydroxyl group in $\mathbf{2 5}$ was esterified with 4"-acetyl cinnamic acid in the presence of EDCI to furnish 26, which was then deprotected under acidic conditions to afford desired conjugates $\mathbf{5 a}-\mathbf{f}$ (Scheme 4).

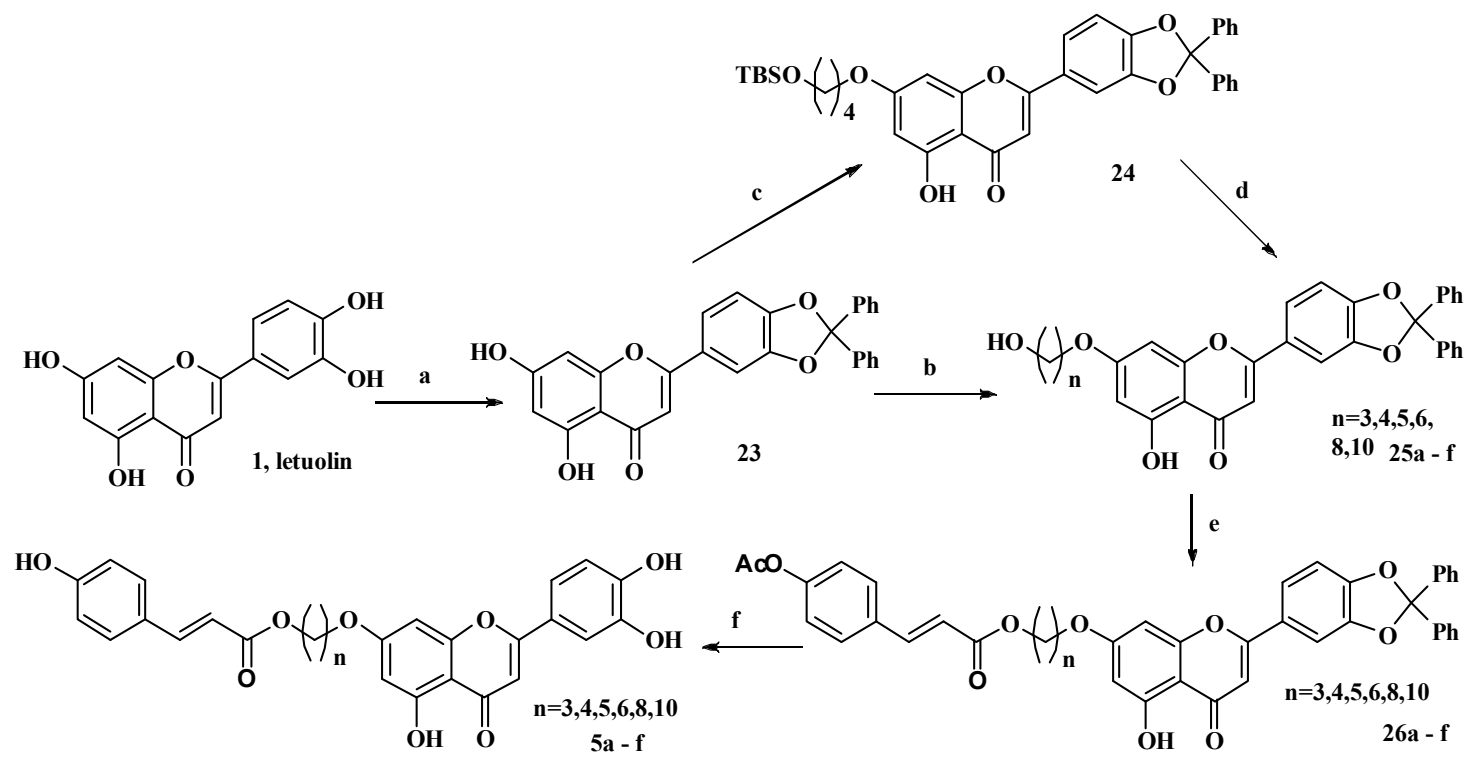

Scheme 4. The synthetic route of target $5 \mathbf{a}-\mathbf{f}$. Reagents and conditions: (a) dichlorodiphenylmethane, diphenyl ether, $165^{\circ} \mathrm{C}, 70 \%$; (b) $\mathrm{TsO}\left(\mathrm{CH}_{2}\right)_{n} \mathrm{OH}(n=3,5,6,8,10), \mathrm{K}_{2} \mathrm{CO}_{3}, \mathrm{MeCN}$, reflux, 28-55\%; (c) $\mathrm{Br}\left(\mathrm{CH}_{2}\right)_{4} \mathrm{OTBS}, \mathrm{K}_{2} \mathrm{CO}_{3}$, acetone, reflux, $12 \mathrm{~h}, 53 \%$; (d) $\mathrm{HF}$, pyridine, MeCN, r.t. overnight, 81\%; (e) 4 "-acetyl cinnamic acid, EDCI, DMAP, TEA, THF, r.t. $24-58 \%$; (f) aq. $38 \% \mathrm{HCl}$ in $\mathrm{AcOH}(v / v$ 1:15), r.t. $28-50 \%$. 
To explore the effect of the length of polymethylene diol linker in the conjugates, a series of conjugates $\mathbf{5 a} \mathbf{a} \mathbf{f}$ with different length of linkers as well as $\mathbf{5} \mathbf{g}$ without linker were prepared.

In general, the inhibitory activity of conjugates $\mathbf{5 a}-\mathbf{f}$ decreased as the length of linker increased (Table 2). Although conjugate $\mathbf{5 a}$ bearing the shortest length of linker in the series was the most active, its $\mathrm{IC}_{50}$ was still lower than 3 bearing ethylene glycol linker. Thus, we adhered to the ethylene glycol linker in the next round of optimization.

Table 2. The enzyme inhibition of Series II compounds.

\begin{tabular}{cccc}
\hline Compound & $\boldsymbol{n}$ & Inhibition Rate at $\mathbf{1 0} \boldsymbol{\mu M} \mathbf{( \% )}$ & $\mathbf{I C}_{\mathbf{5 0}}(\boldsymbol{\mu M})$ \\
\hline $\mathbf{5 a}$ & 3 & $81.4 \pm 3.8$ & $5.26 \pm 0.72$ \\
$\mathbf{5 b}$ & 4 & $68.1 \pm 5.8$ & $10.36 \pm 1.02$ \\
$\mathbf{5 c}$ & 5 & $62.6 \pm 6.4$ & $20.63 \pm 1.44$ \\
$\mathbf{5 d}$ & 6 & $42.4 \pm 3.2$ & \\
$\mathbf{5 e}$ & 8 & $36.1 \pm 2.6$ & $27.79 \pm 1.34$ \\
$\mathbf{5 f}$ & 10 & $58.2 \pm 3.3$ & \\
$\mathbf{5 g}$ & - & $41.4 \pm 4.4$ & $7.02 \pm 0.85$ \\
$\mathbf{1}$ & - & $68.6 \pm 8.9$ & $2.19 \pm 0.34$ \\
$\mathbf{3}$ & 2 & $64.8 \pm 6.0$ & \\
\hline
\end{tabular}

\subsection{Design, Synthesis, and Activity of Series III Compounds}

\subsubsection{Design, Synthesis, and Enzyme Inhibition Activity of Series III Compounds}

Next, we tried to optimize the other segment (i.e., cinnamoyl segment) in the conjugate, through replacing the $p$-hydroxy by other substituents on phenyl ring, and the phenyl, by heterocycles and cyclohexane (Figure 4, Table 3 and Figure 5). In addition, the ester bond between the cinnamoyl segment and the linker was replaced by amide group to make this possibly labile bond more stable (Figure 5).

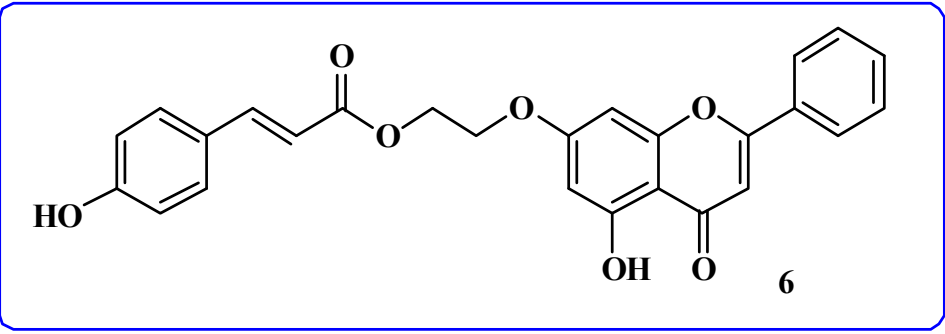

Figure 4. The structure of compound 6.

Table 3. The structure of compounds $7 \mathbf{a}-7 \mathbf{j}$ and $\mathbf{7 q}$.

\begin{tabular}{|c|c|c|c|}
\hline Compound & $\mathbf{R}=$ & Compound & $\mathbf{R}=$ \\
\hline $7 a$ & $\mathrm{H}$ & $7 g$ & $4-\mathrm{NO}_{2}$ \\
\hline $7 \mathrm{~b}$ & $2-\mathrm{OH}$ & $7 \mathrm{~h}$ & $4-\mathrm{NMe}_{2}$ \\
\hline $7 c$ & $3-\mathrm{OH}$ & $7 \mathbf{i}$ & 4-OMe \\
\hline $7 d$ & 3,4-diOH & $7 \mathbf{j}$ & $4-\mathrm{C}\left(\mathrm{CH}_{3}\right)_{3}$ \\
\hline $7 e$ & $4-\mathrm{F}$ & $7 q$ & 4-OAc \\
\hline $7 f$ & $4-\mathrm{Cl}$ & & \\
\hline
\end{tabular}




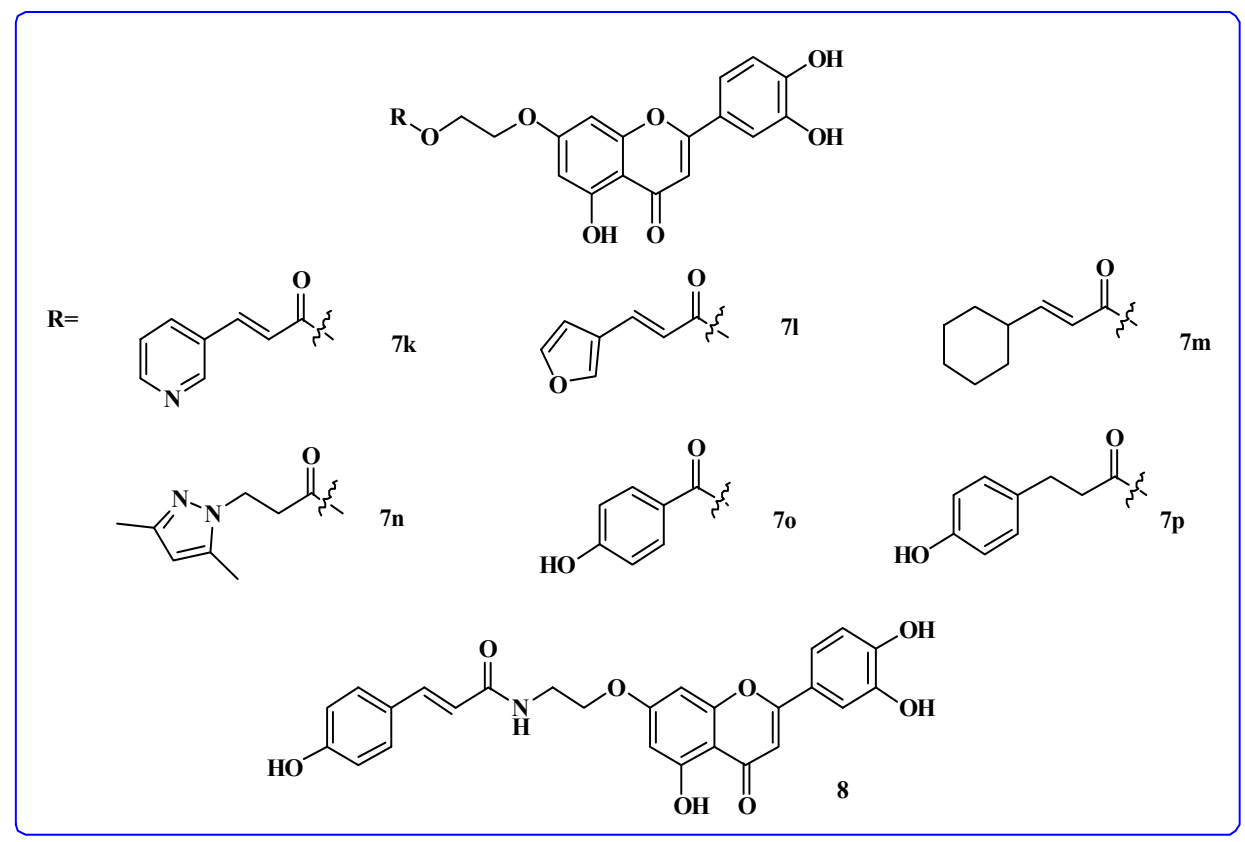

Figure 5. The structure of compound $7 \mathbf{k}-7 \mathbf{p}$ and 8 .

The general synthetic routes of Series III compounds were much similar to Series II. It should be noted that the acyl chloride method was chosen for compound $\mathbf{7 b}, \mathbf{7 d}$, and $\mathbf{7 o}$ when the ester bond compounds were prepared (Scheme 5).
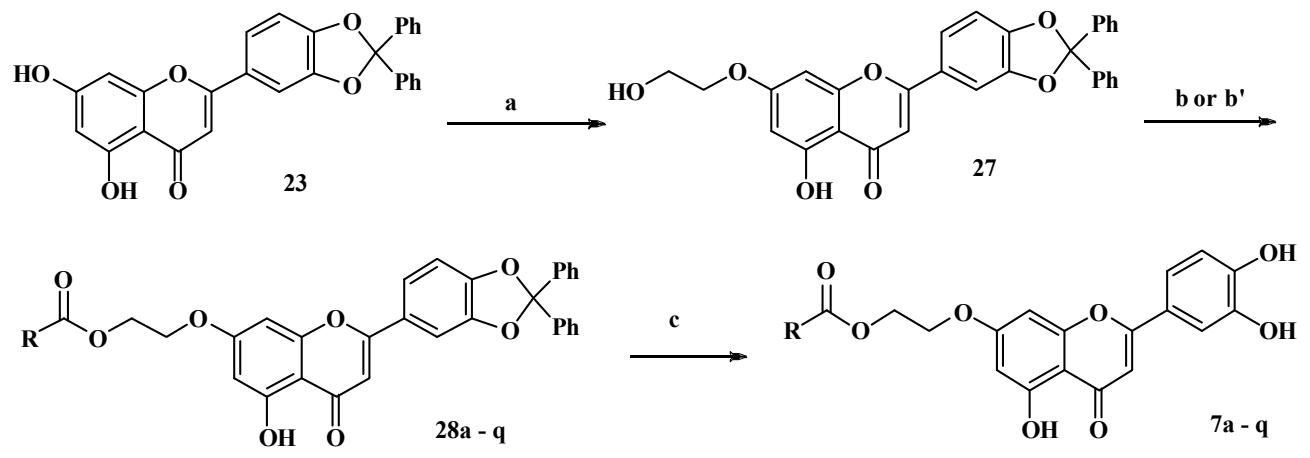

Scheme 5. The general synthetic route of Series III compounds. Reagents and conditions: (a). $\mathrm{TsOCH}_{2} \mathrm{CH}_{2} \mathrm{OH}, \mathrm{K}_{2} \mathrm{CO}_{3}, \mathrm{MeCN}$, reflux, 57\%; (b) carboxylic acid, EDCI, DMAP, TEA, THF, $40{ }^{\circ} \mathrm{C}$, or $\left(\mathbf{b}^{\prime}\right)$ carboxylic acid, $\mathrm{SOCl}_{2}, \mathrm{DMF}, \mathrm{DCE}, 80^{\circ} \mathrm{C}, 2 \mathrm{~h}$ and Py, DCM, r.t. $4 \mathrm{~h} 35-82 \%$; (c) aq. $38 \% \mathrm{HCl}$ in $\mathrm{AcOH}(v / v$ 1:15), r.t. $31-88 \%$.

As shown in Table 4, conjugate 7k with pyridine in placement of phenol exhibited the most potent inhibitory activity with an $\mathrm{IC}_{50}$ of $0.15 \mu \mathrm{M}$ in the series, with an approximate 10-fold enhancement compared with the flavone segment $\mathbf{1}$ or conjugate $\mathbf{3}$. It is worth noting that many conjugates exhibited an inhibition rate of approximately $60 \%$ at $10 \mu \mathrm{M}$, while possessing $50 \%$ inhibition even at low concentration (e.g., $7 \mathrm{k}, 7 \mathbf{l}$ with $\mathrm{IC}_{50} \mathrm{~s}$ of $0.1-0.2 \mu \mathrm{M}$ ). It was difficult to reach the maximum inhibition rate of $80-90 \%$ even at $20 \mu \mathrm{M}$ or $50 \mu \mathrm{M}$. An S-curve for $\mathrm{IC}_{50}$ calculation of several compounds is shown in the Supplementary Materials. 
Table 4. The enzyme activity of Series III compounds.

\begin{tabular}{|c|c|c|c|c|c|}
\hline Compound & $\begin{array}{l}\text { Inhibition rate } \\
\text { at } 10 \mu \mathrm{M}(\%)\end{array}$ & $\mathrm{IC}_{50}(\mu \mathrm{M})$ & Compound & $\begin{array}{l}\text { Inhibition rate } \\
\text { at } 10 \mu \mathrm{M}(\%)\end{array}$ & $\mathrm{IC}_{50}(\mu \mathrm{M})$ \\
\hline $7 a$ & $57.5 \pm 7.5$ & $2.49 \pm 0.32$ & $7 q$ & $25.7 \pm 4.6$ & - \\
\hline $7 \mathrm{~b}$ & $67.7 \pm 12.5$ & $2.27 \pm 0.42$ & $7 \mathbf{k}$ & $54.4 \pm 3.5$ & $0.15 \pm 1.01$ \\
\hline $7 \mathrm{c}$ & $66.7 \pm 8.3$ & $1.44 \pm 0.18$ & 71 & $59.5 \pm 7.1$ & $0.37 \pm 0.25$ \\
\hline $7 d$ & $66.6 \pm 7.1$ & $0.23 \pm 0.02$ & $7 \mathrm{~m}$ & $22.2 \pm 7.1$ & - \\
\hline $7 e$ & $28.5 \pm 7.1$ & - & $7 n$ & $55.2 \pm 7.1$ & $3.05 \pm 0.39$ \\
\hline $7 f$ & $21.3 \pm 7.1$ & - & 70 & $51.9 \pm 1.9$ & - \\
\hline $7 \mathrm{~g}$ & $73.9 \pm 7.1$ & $0.96 \pm 1.55$ & $7 p$ & $56.7 \pm 4.4$ & $4.39 \pm 0.34$ \\
\hline $7 \mathrm{~h}$ & $53.8 \pm 4.4$ & $6.58 \pm 1.16$ & 8 & $59.5 \pm 4.4$ & $4.15 \pm 1.97$ \\
\hline $7 \mathbf{i}$ & $28.9 \pm 4.4$ & - & 6 & $20.5 \pm 4.4$ & - \\
\hline $7 \mathbf{j}$ & $37.6 \pm 4.4$ & - & 1 & $64.8 \pm 6.0$ & $1.09 \pm 1.34$ \\
\hline 3 & $68.6 \pm 8.9$ & $1.87 \pm 1.91$ & & & \\
\hline
\end{tabular}

The structure activity relationship (SAR) for Series III can be summarized as follows: (1) The hydroxy on ring B of flavone segment was necessary for activity (possibly through hydrogen bonding). The inhibitory activity of conjugates decreased obviously when the hydroxy was replaced by hydrogen or other groups (3 vs. 6). (2) The hydroxy on the benzene ring of cinnamoyl segment was also important. The inhibitory activity of conjugates decreased when the hydroxy was replaced by other non-polar substituents, or by methylation or esterification $(\mathbf{3}, \mathbf{7 b}, \mathbf{7 c}, \mathbf{7 d}$ vs. $\mathbf{7 a}, \mathbf{7 i}, \mathbf{7 q})$. However, the position and number of hydroxyls did not have a significant impact on the activity ( $7 b, 7 c$ vs. 3). (3) The derivatives with aromatic heterocyclic showed favorable activity, especially the compound with pyridine ring. (4) When the aromatic or heteroaromatic ring $(7 \mathbf{k}-7 \mathbf{l}, 7 \mathbf{n}-7 \mathbf{p})$ was replaced by cyclohexyl group $(7 \mathbf{m})$, the activity decreased significantly.

\subsubsection{Cytotoxicity of Series III Compounds}

It is crucial for the BACE1 inhibitors to exert their activities at sub-toxic concentration, and thus their cytotoxicity was assessed in HEK293 cells by 3-[4,5-dimethylthiazol-2-yl]-2,5-diphenyl-tetrazolium bromide (MTT) assays (Table 5). Among the compounds, $\mathbf{7 a}, \mathbf{7 h}, \mathbf{7 q}, \mathbf{7 k}$, and $\mathbf{8}$ were the least cytotoxic $\left(\mathrm{IC}_{50}>100 \mu \mathrm{M}\right)$, and $7 \mathbf{c}$ and $7 \mathbf{p}$ were weak cytotoxic $\left(\mathrm{IC}_{50}=90 \mu \mathrm{M}\right)$. Unfortunately, there was no obvious relationship between the structures and their cytotoxicity.

Table 5. Cytotoxicity study of Series III compounds.

\begin{tabular}{cccc}
\hline Compound & IC $_{\mathbf{5 0}}(\boldsymbol{\mu M})$ & Compound & $\mathrm{IC}_{\mathbf{5 0}}(\boldsymbol{\mu M})$ \\
\hline $\mathbf{7 a}$ & $>100$ & $\mathbf{7 q}$ & $>100$ \\
$\mathbf{7 b}$ & 15.6 & $\mathbf{7 k}$ & $>100$ \\
$\mathbf{7} \mathbf{c}$ & 90 & $\mathbf{7 1}$ & 9.51 \\
$\mathbf{7 d}$ & 16.7 & $\mathbf{7} \mathbf{m}$ & 14.4 \\
$\mathbf{7 e}$ & 16.8 & $\mathbf{7 n}$ & 33 \\
$\mathbf{7 f}$ & 9.97 & $\mathbf{7 o}$ & 10.3 \\
$\mathbf{7 g}$ & 21.8 & $\mathbf{7} \mathbf{p}$ & 90 \\
$\mathbf{7 h}$ & $>100$ & $\mathbf{5 g}$ & 4.21 \\
$\mathbf{7 i}$ & 3.94 & $\mathbf{6}$ & 28.3 \\
$\mathbf{7 j}$ & 20.3 & $\mathbf{8}$ & $>100$ \\
$\mathbf{3}$ & 62.4 & 1 & 39.8 \\
\hline
\end{tabular}

\subsubsection{Enzyme Inhibition in Cells}

To assess the cellular BACE1 inhibitory activity of the conjugates, $\mathbf{7 a - d}, \mathbf{7} \mathbf{i}$, and $\mathbf{7 k}$ were incubated in APP overexpressing HEK293 cells and their inhibition on the three main $A \beta$ species $A \beta-38, A \beta-40$, and $A \beta-42$ - the main amyloidogenic peptides produced by BACE1 cleavage of APP peptide-was measured by an ELISA-like immunoassay method. $A \beta$ levels were normalized to the protein 
concentration in the lysate in order to rule out differences in total cell number per well of the culture plate. Additionally, the normalized A $\beta$ level was set to $100 \%$ for the DMSO-treated control.

The $A \beta$ levels upon treatment of different compounds are shown in Figure $6(A \beta-42)$ and the Supplementary Materials (A $\beta-38$ and $A \beta-40)$. At the higher concentrations $(10,25$, and $50 \mu \mathrm{M}), 7 \mathbf{b}-\mathbf{d}$ and 1 dose-dependently reduced $A \beta$ levels. It is worth noting that $7 \mathrm{c}$ showed an obvious inhibition $\mathrm{A} \beta-42$ level at $25 \mu \mathrm{M}$. However, $7 \mathbf{i}$ and $7 \mathbf{k}$ did not reduce $A \beta$ levels, and even increased $A \beta-42$ levels.

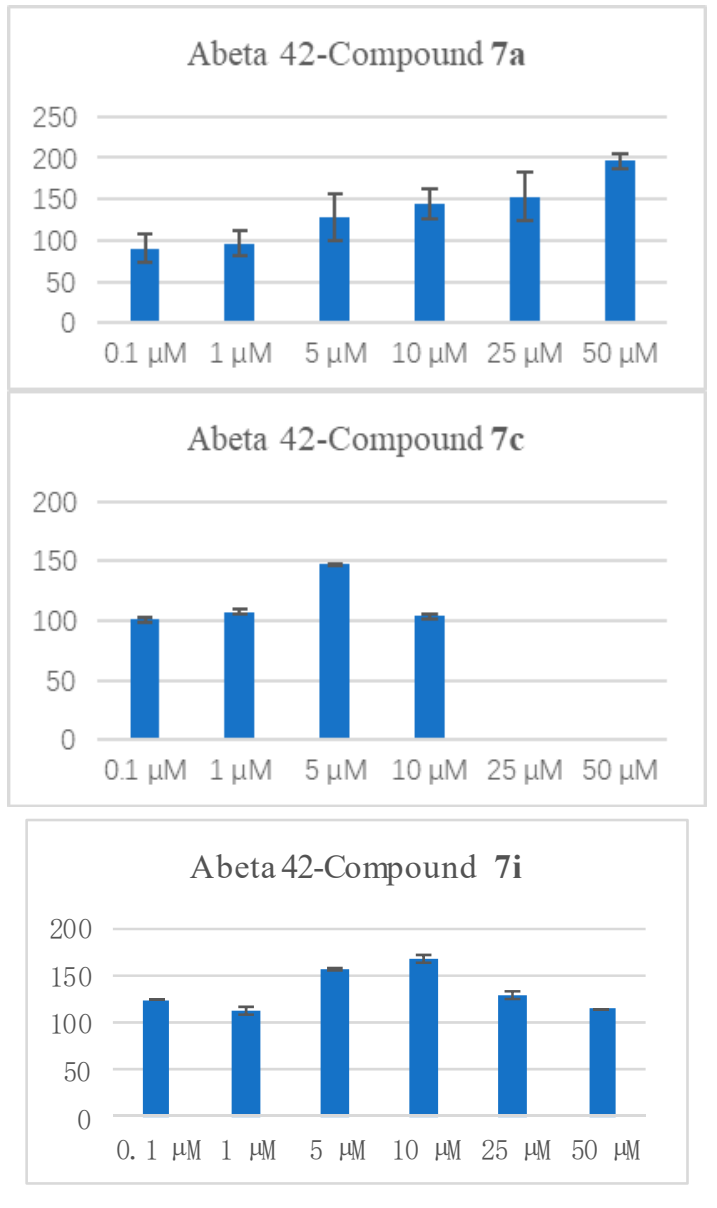

Abeta 42- Luteolin (1)

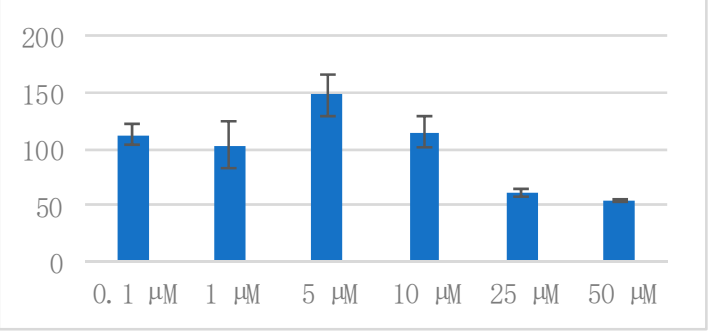

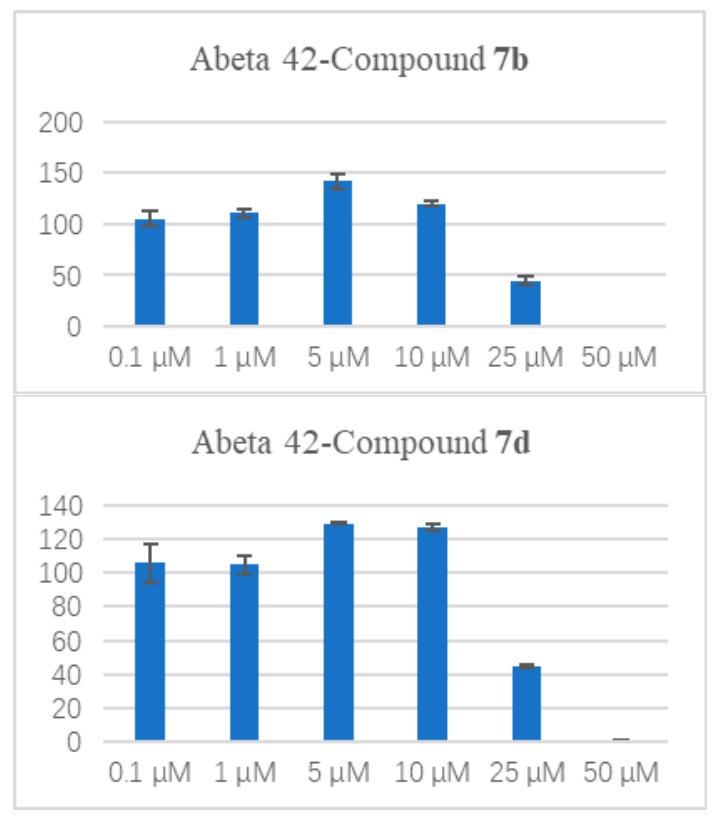
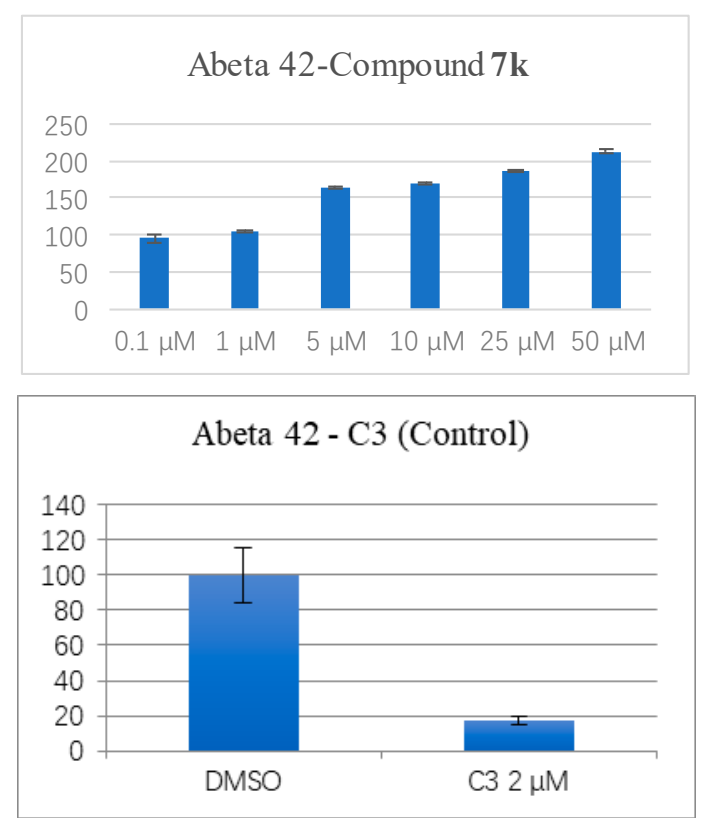

Figure 6. The normalized A $\beta-42$ level in amyloid precursor protein (APP) overexpressing HEK293 cells after the treatment of $\mathbf{7 a}-\mathbf{d}, \mathbf{7 i}, \mathbf{7 k}$, and luteolin compared with DMSO (100\%), the known inhibitor C3 [15].

\subsubsection{Enzyme Kinetics Experiment and Enzyme Selectivity}

We are interested to know if the most active conjugates derived from $\mathbf{1}$ and $\mathbf{3}$ will keep or change their non-competitive mode of inhibition. The Dixon plot was used to determine the kinetics of 41 , 7c, and 7k inhibiting BACE1. As shown in Figure 7, the three lines that stand for different substrate 
concentration intersect on the $x$-axis, demonstrating that $7 \mathrm{c}$ was a non-competitive inhibitor with a Ki value of $1.2 \mu \mathrm{M}$, and that 41 and $7 \mathbf{k}$ were in mix-competitive mode (Supplementary Materials).

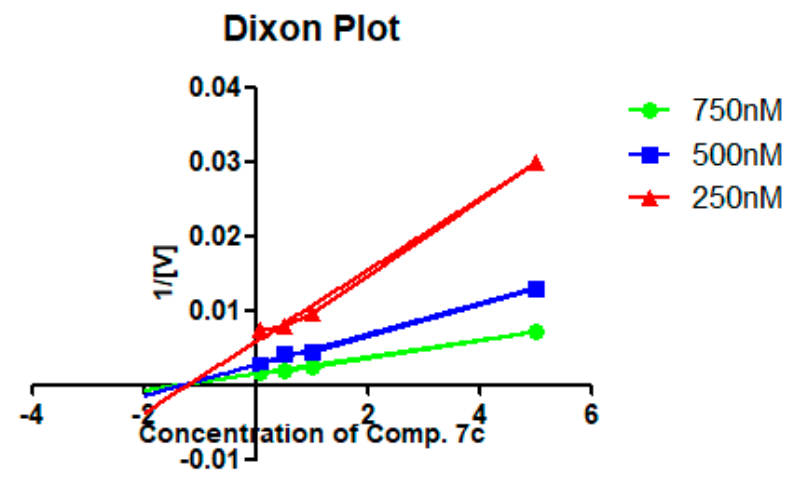

Figure 7. Kinetic analysis of 7c. The inhibitor was tested in the presence of different concentrations of substrate: $250 \mathrm{nM}(\mathbf{\Delta}), 500 \mathrm{nM}(\boldsymbol{\bullet})$, and $750 \mathrm{nM}(\bullet)$. BACE1 ( $\beta$-site amyloid precursor protein cleaving enzyme 1) inhibition was analyzed in the presence of different concentrations of sample as follows: $0.1 \mu \mathrm{M}, 0.5 \mu \mathrm{M}, 1.0 \mu \mathrm{M}, 5.0 \mu \mathrm{M}$.

As BACE1 is a member of aspartyl protease family, its selective inhibition over other closely related proteases is required to avoid possible severe side effects. We measured the inhibition of $7 \mathbf{c}$, 7k, and 8 on BACE-2 and renin, and found 7c and 7k showed very good selectivity (ca. 2-3 orders of magnitude) on BACE1 over BACE2 and renin (Table 6).

Table 6. The enzyme selectivity of compound $7 \mathbf{c}, 7 \mathbf{k}$, and 8 .

\begin{tabular}{cccc}
\hline Compound & ${\text { BACE1 } \text { IC }_{\mathbf{5 0}}(\boldsymbol{\mu M})}$ & BACE2 IC $_{\mathbf{5 0}}(\boldsymbol{\mu M})$ & Renin IC $_{\mathbf{5 0}}(\boldsymbol{\mu M})$ \\
\hline $7 \mathrm{c}$ & $1.44 \pm 0.18$ & $>100$ & $>100$ \\
$7 \mathbf{k}$ & $0.15 \pm 1.01$ & $>100$ & $>100$ \\
$\mathbf{8}$ & $4.15 \pm 1.97$ & $>100$ & 25.42 \\
\hline
\end{tabular}

To assess the potential of these conjugates as CNS drug candidates, the ability to cross the BBB (blood-brain barrier) is worthy evaluation. Thus, we calculated cLogP and BBB penetration for several representative conjugates by an open source software [16]. The result (Figure S2) showed that some of them (e.g., 7k) may have the ability to cross the BBB.

In summary, the extensive optimization of flavone-cinnamic acid conjugates revealed some more potent BACE1 inhibitors including 7c and 7k. On the basis of the analysis of multiple bioassay data, 7c exhibited improved activity and weaker toxicity in cells, demonstrating an improvement from the starting point of this work, conjugate 3. Moreover, $7 \mathrm{c}$ also showed non-competitive mode of BACE1 inhibition and selectivity over other related enzymes such as BACE2 and renin, suggesting it may retain the selective inhibition of BACE1 as an allosteric inhibitor to facilitate the reduction of APP processing and spare other BACE1 functions. Combining the computational result of LogP and BBB-penetrating ability, it was demonstrated that such a conjugate may be served as a drug candidate for AD therapy, and in-depth PD (pharmacodynamic) and PK (pharmacokinetic) studies in animals are warranted.

\section{Materials and Methods}

\subsection{Chemical Synthesis}

In this part, the preparation for representative conjugates are shown. Other compounds and also the NMR and mass spectrometry (MS) data for structural characterization for all compounds are included in the Supplementary Materials. 


\subsubsection{General Methods}

All chemicals and reagents were purchased from Beijing Innochem Science and Technology Co. Ltd. (Beijing, China), Sinopharm Chemical Reagent Co. Ltd. (Beijing, China), and thin-layer chromatography (TCI). The 200-300 mesh silica gel used for flash column chromatography was purchased from Rushanshi Shuangbang Xincailiao Co. Ltd. (Rushan, Shandong, China). Visualization on TLC (analytical thin layer chromatography) was achieved by the use of UV light (254 and $365 \mathrm{~nm}$ ). All solvents were purified and dried according to the standard procedures. The purification was performed on flash column chromatography. The high performance liquid chromatography (HPLC)-electrospray ionization (ESI)-mass spectrometry (MS) analysis was carried out in an Agilent 1260 Infinity HPLC system (Agilent Technologies, Waldbronn, Germany) equipped with a reversed phase $4.68 \times 50 \mathrm{~mm}(1.8 \mu \mathrm{m}) \mathrm{XDB}-\mathrm{C} 18$ Column and consisted of a binary solvent delivery system, an auto sampler, a column temperature controller, and a UV detector. The mass spectra were acquired by a 6120 Quadrupole LC-MS mass spectrometer (Agilent Technologies, Waldbronn, Germany) connected to the HPLC system via an ESI interface. Proton and carbon magnetic resonance spectra $\left({ }^{1} \mathrm{H}-\mathrm{NMR}\right.$ and ${ }^{13} \mathrm{C}-\mathrm{NMR}$ ) were recorded on a Bruker BioSpin AG 300 or $400 \mathrm{MHz}$ spectrometer or Varian 400, 500 , or $600 \mathrm{MHz}$ spectrometer. ${ }^{1} \mathrm{H}-\mathrm{NMR}$ data were reported as follows: chemical shifts, multiplicity ( $\mathrm{s}=$ singlet, $\mathrm{d}=$ doublet, $\mathrm{t}=$ triplet, $\mathrm{q}=$ quartet, $\mathrm{m}=$ multiplet $)$, coupling constant $(\mathrm{s})$ in $\mathrm{Hz}$, integration. All tested compounds $\mathbf{4 a}-\mathbf{1}, \mathbf{5 a}-\mathbf{g}, \mathbf{6}, \mathbf{7 a}-\mathbf{q}$, and $\mathbf{8}$ were $\geq 95 \%$ pure by HPLC (column C18 $4.6 \times 250$ $\mathrm{mm} 5 \mu \mathrm{m}$, mobile phase: acetonitrile-water (70:30 or 80:20 or 90:10 in $10 \mathrm{~min}$ ), flow rate $1.0 \mathrm{~mL} / \mathrm{min}$, detected at $254 \mathrm{~nm}$ ).

\subsubsection{Synthesis of Compound $\mathbf{4} \mathbf{j}$}

7-(benzyloxy)-2-(3,4-bis(benzyloxy)phenyl)-3,5-dihydroxy-4H-chromen-4-one (16): To a solution of rutin (610 mg, $1 \mathrm{mmol})$ in DMF (30 mL), BnBr (684 mg, $4 \mathrm{mmol})$ and $\mathrm{K}_{2} \mathrm{CO}_{3}(552 \mathrm{mg}, 4 \mathrm{mmol})$ were added. The solution was stirred at $50{ }^{\circ} \mathrm{C}$ for $3 \mathrm{~h}$. Water $(100 \mathrm{~mL})$ was added, and the solution was cooled to $0{ }^{\circ} \mathrm{C}$ for overnight. The solid 15 was collected by suction filtration and dissolved in $95 \%$ alcohol (20 $\mathrm{mL})$, and hydrochloric acid $(3 \mathrm{~mL})$ was added. After stirring for $2 \mathrm{~h}$ at $70{ }^{\circ} \mathrm{C}$, solid was precipitated in the solution. Then, compound 16 (740 $\mathrm{mg}, 84 \%)$ was collected by suction filtration after the solution was cooled to r.t.

7-(benzyloxy)-2-(3,4-bis(benzyloxy) phenyl)-3-(2-((tert-butyldimethylsilyl)oxy)ethoxy)-5-hydroxy-4H-chromen4-one (17): To a solution of 16 (147 mg, $0.26 \mathrm{mmol})$ in DMF (5 mL), $\mathrm{K}_{2} \mathrm{CO}_{3}$ (54 mg, $\left.0.39 \mathrm{mmol}\right)$ and (2-bromoethoxy)(tert-butyl)dimethylsilane $(93 \mathrm{mg}, 0.39 \mathrm{mmol})$ were added. After stirring at $80{ }^{\circ} \mathrm{C}$ for $12 \mathrm{~h}$, water $(20 \mathrm{~mL})$ was added and extracted with ethyl acetate $(25 \mathrm{~mL} \times 2)$. The organic layer was gathered, dried over $\mathrm{Na}_{2} \mathrm{SO}_{4}$, filtered, and concentrated in vacuo. The crude product was purified by column chromatography (PE/acetone $=10: 1)$ to give 17 as yellow solids (101 mg, 52.7\%).

3-(2-((tert-butyldimethylsilyl)oxy)ethoxy)-2-(3,4-dihydroxyphenyl)-5,7-dihydroxy-4H-chromen-4-one (18): To a mixture of $17(100 \mathrm{mg}, 0.14 \mathrm{mmol})$ and $\mathrm{Pd} / \mathrm{C}(150 \mathrm{mg})$ in THF $(5 \mathrm{~mL})$ and ethanol $(5 \mathrm{~mL})$, 1,4-cyclohexadiene $(659 \mu \mathrm{L}, 7 \mathrm{mmol})$ was added. After stirring at $80^{\circ} \mathrm{C}$ for $12 \mathrm{~h}$, the solution was concentrated in vacuo after suction filtration. The crude product was purified by column chromatography (PE/acetone/THF $=9: 2: 1)$ to give 18 as yellow solids $(49 \mathrm{mg}, 78.6 \%)$.

2-(3,4-bis(methoxymethoxy)phenyl)-3-(2-((tert-butyldimethylsilyl)oxy)ethoxy)-5-hydroxy-7-(methoxymethoxy)4H-chromen-4-one (19): The starting material $18(310 \mathrm{mg}, 0.67 \mathrm{mmol})$ was dissolved in DCM (5 mL), and $\operatorname{MOMCl}(0.18 \mathrm{~mL}, 2.16 \mathrm{mmol})$ was added at $-10^{\circ} \mathrm{C}$. After 10 mins stirring, DIEA (0.44 mL, $\left.2.16 \mathrm{mmol}\right)$ was added slowly and the suspension heated to $0{ }^{\circ} \mathrm{C}$. Saturated sodium bicarbonate $(10 \mathrm{~mL})$ was added to quench reaction after $1 \mathrm{~h}$. The dichloromethane layer was separated, then the aqueous phase was extracted with dichloromethane $(10 \mathrm{~mL})$. The organic phase was merged, then washed with water and brine, dried over $\mathrm{Na}_{2} \mathrm{SO}_{4}$, filtered, and concentrated in vacuo. The residue was purified by column chromatography (petroleum ether/acetone $=10: 1)$ to give 19 as yellow solids $(230 \mathrm{mg}, 57.4 \%$ ). 
2-(3,4-bis(methoxymethoxy)phenyl)-5-hydroxy-3-(2-hydroxyethoxy)-7-(methoxymethoxy)-4H-chromen-4-one (20): A solution of compound $19(230 \mathrm{mg}, 0.39 \mathrm{mmol})$ and CsF (304 mg, $2 \mathrm{mmol})$ in dry DMF (2 mL) was heated to $100{ }^{\circ} \mathrm{C}$ for $2 \mathrm{~h}$. The resulting mixture was diluted with water $(5 \mathrm{~mL})$ and extracted with ethyl acetate $(10 \mathrm{~mL} \times 3)$. The organic layer was dried over $\mathrm{Na}_{2} \mathrm{SO}_{4}$, filtered, and concentrated in vacuo. The crude product was purified by column chromatography (petroleum ether/acetone $=5: 1$ ) to give 20 as yellow solid (154 $\mathrm{mg}, 83.0 \%)$.

2-((2-(3,4-bis(methoxymethoxy)phenyl)-5-hydroxy-7-(methoxymethoxy)-4-oxo-4H-chromen-3-yl)oxy)ethyl (E)-3-(4-acetoxyphenyl)acrylate (21): To a solution of 4-acetoxycinnamic acid (41 mg, $0.2 \mathrm{mmol}) \mathrm{in}$ THF $(1 \mathrm{~mL}), \mathrm{EDCI}(38 \mathrm{mg}, 0.2 \mathrm{mmol}), \mathrm{DMAP}(6 \mathrm{mg}, 0.05 \mathrm{mmol})$, and $\mathrm{Et}_{3} \mathrm{~N}(45 \mu \mathrm{L}, 0.3 \mathrm{mmol})$ were added. Then, 16a $(27 \mathrm{mg}, 0.066 \mathrm{mmol})$ in THF $(1 \mathrm{~mL})$ was added under nitrogen. The solution was stirred at r.t. for $12 \mathrm{~h}$. The organic layer was concentrated in vacuo. The residue was purified by column chromatography (petroleum ether/EtOAc $=3: 1$ ) to give 21 as white solid ( $24 \mathrm{mg}, 45.0 \%$ ).

2-((2-(3,4-bis(methoxymethoxy)phenyl)-5-hydroxy-7-(methoxymethoxy)-4-oxo-4H-chromen-3-yl)oxy)ethyl (E)-3-(4-hydroxyphenyl)acrylate (22): Compound 21 (24 mg, $0.036 \mathrm{mmol})$ was dissolved in a solution of $\mathrm{CH}_{2} \mathrm{Cl}_{2}(1 \mathrm{~mL})$ and $\mathrm{K}_{2} \mathrm{CO}_{3}(1.38 \mathrm{mg}, 0.01 \mathrm{mmol}) \mathrm{MeOH}$ solution $(1 \mathrm{~mL})$ was added under argon at room temperature. After stirring for $12 \mathrm{~h}$, the resulting mixture was concentrated in vacuo and purified by column chromatography (DCM/acetone $=30: 1)$ to give 22 as yellow solid $(12 \mathrm{mg}, 56.2 \%)$.

2-((2-(3,4-dihydroxyphenyl)-5,7-dihydroxy-4-oxo-4H-chromen-3-yl)oxy)ethyl(E)-3-(4-hydroxyphenyl)acrylate (4j): To a solution of $22(12 \mathrm{mg}, 0.019 \mathrm{mmol})$ in $0.2 \mathrm{~mL}$ acetone, $38 \% \mathrm{HCl} / \mathrm{AcOH}(v / v=1: 15,1.8 \mathrm{~mL})$ mixture was added at room temperature. The solution was stirred at room temperature. After $24 \mathrm{~h}$, yellow solid precipitated and the precipitate was filtered off, washed with water, and dried to give $4 \mathbf{j}$ (5.1 $\mathrm{mg}, 53.5 \%)$ as yellow solid.

\subsubsection{Synthesis of Compound 5a-f}

Luteolin 3',4'-O-diphenylmethylidene (23): Dichlorodiphenylmethane (20 $\mu \mathrm{L}, 1.1 \mathrm{mmol})$ was added to a stirred mixture of luteolin $(20 \mathrm{mg}, 0.07 \mathrm{mmol})$ in diphenyl ether $(1.4 \mathrm{~mL})$, and the reaction mixture was heated at $165{ }^{\circ} \mathrm{C}$ for $2.5 \mathrm{~h}$. After being cooled to room temperature, the reaction solution was poured into petroleum ether $(20 \mathrm{~mL})$, and the precipitation was filtered and washed with petroleum ether. The filter residue was dissolved into acetone, and the resulting solution was concentrated and purified by column chromatography (petroleum ether/EtOAc $=4: 1)$ to give 45 as yellow solid $(22 \mathrm{mg}, 70 \%)$.

7-(4-((tert-butyldimethylsilyl)oxy)butoxy)-2-(2,2-diphenylbenzo[d][1,3]dioxol-5-yl)-5-hydroxy-4H-chromen-4one (24): TBSCl (452 mg, $3.0 \mathrm{mmol})$ and imidazole $(204 \mathrm{mg}, 3.0 \mathrm{mmol})$ were added to a solution of 4- bromobutanol (300 mg, $2.0 \mathrm{mmol})$ in DMF (3 mL) at room temperature. After stirring overnight, the resulting mixture was poured into ice-water, and extracted with EtOAc. The organic layer was washed with saturated aqueous $\mathrm{NaHCO}_{3}$ and $\mathrm{NaCl}$ successively, dried over $\mathrm{Na}_{2} \mathrm{SO}_{4}$, filtered, and concentrated in vacuo to give $\mathrm{Br}\left(\mathrm{CH}_{2}\right)_{4}$ OTBS crude. The crude was dissolved in acetone $(3 \mathrm{~mL})$, then $23(225 \mathrm{mg}, 0.5 \mathrm{mmol})$ and $\mathrm{K}_{2} \mathrm{CO}_{3}(276 \mathrm{mg}, 2 \mathrm{mmol})$ were added. The reaction mixture was then refluxed overnight and concentrated in vacuo. The residue was purified by column chromatography (petroleum ether/acetone $=7: 1)$ to give 24 as yellow solid $(136 \mathrm{mg}, 42.8 \%)$.

2-(2,2-diphenylbenzo[d][1,3]dioxol-5-yl)-5-hydroxy-7-(3-hydroxypropoxy)-4H-chromen-4-one (25a): Potassium carbonate $(143 \mathrm{mg}, 1.0 \mathrm{mmol})$ was added to a solution of $23(315 \mathrm{mg}, 0.7 \mathrm{mmol})$ and $\mathrm{TsO}\left(\mathrm{CH}_{2}\right){ }_{3} \mathrm{OH}$ (230 mg, $1.0 \mathrm{mmol}$ ) in $\mathrm{CH}_{3} \mathrm{CN}(4 \mathrm{~mL})$ at room temperature. The reaction mixture was then refluxed overnight. The resulting mixture was poured into ice-water, adjusted to neutral $\mathrm{pH}$ with aqueous $\mathrm{HCl}(5 \%)$, and extracted with EtOAc. The organic layer was washed with brine, dried over $\mathrm{Na}_{2} \mathrm{SO}_{4}$, filtered, and concentrated in vacuo. The residue was purified by column chromatography (petroleum ether/acetone $=5: 1)$ to give $\mathbf{2 5 a}$ as yellow solid $(218 \mathrm{mg}, 34.2 \%)$. 
2-(2,2-diphenylbenzo[d][1,3]dioxol-5-yl)-5-hydroxy-7-((5-hydroxypentyl)oxy)-4H-chromen-4-one (25c): Compound $25 \mathrm{c}(60 \mathrm{mg}, 27.8 \%)$ was synthesized from $\mathrm{TsO}\left(\mathrm{CH}_{2}\right)_{5} \mathrm{OH}(104 \mathrm{mg}, 0.4 \mathrm{mmol})$, according to the procedure used to prepare $\mathbf{2 5 a}$, obtained as yellow solid.

2-(2,2-diphenylbenzo[d][1,3]dioxol-5-yl)-5-hydroxy-7-((6-hydroxyhexyl)oxy)-4H-chromen-4-one

(25d):

Compound 25d (132 mg, 47.5\%) was synthesized from $\mathrm{TsO}\left(\mathrm{CH}_{2}\right)_{6} \mathrm{OH}(133 \mathrm{mg}, 0.49 \mathrm{mmol})$, according to the procedure used to prepare $25 \mathbf{a}$, obtained as yellow solid.

2-(2,2-diphenylbenzo[d][1,3]dioxol-5-yl)-5-hydroxy-7-((8-hydroxyoctyl)oxy)-4H-chromen-4-one Compound 25 e $(237 \mathrm{mg}, 55.3 \%)$ was synthesized from $\mathrm{TsO}\left(\mathrm{CH}_{2}\right)_{8} \mathrm{OH}(288 \mathrm{mg}, 0.96 \mathrm{mmol})$, according to the procedure used to prepare $25 \mathbf{a}$, obtained as yellow solid.

2-(2,2-diphenylbenzo[d][1,3]dioxol-5-yl)-5-hydroxy-7-((10-hydroxydecyl)oxy)-4H-chromen-4-one Compound $25 \mathrm{f}(212 \mathrm{mg}, 49.9 \%)$ was synthesized from $\mathrm{TsO}\left(\mathrm{CH}_{2}\right){ }_{10} \mathrm{OH}(340 \mathrm{mg}, 1.04 \mathrm{mmol})$, according to the procedure used to prepare $25 \mathbf{a}$, obtained as yellow solid.

2-(2,2-diphenylbenzo[d][1,3]dioxol-5-yl)-5-hydroxy-7-(4-hydroxybutoxy)-4H-chromen-4-one (25b): HF $(743 \mu \mathrm{L}, 17.1 \mathrm{mmol})$ and pyridine $(1.4 \mathrm{~mL}, 17.1 \mathrm{mmol})$ were added to a solution of 24 (36 $\mathrm{mg}$, $0.057 \mathrm{mmol})$ in $\mathrm{MeCN}(1 \mathrm{~mL})$ at room temperature. After stirring overnight, the reaction was quenched by $1 \mathrm{~N}$ hydrochloric acid, and extracted with EtOAc. The organic layer was washed with saturated aqueous $\mathrm{NaHCO}_{3}$ and $\mathrm{NaCl}$ successively, dried over $\mathrm{Na}_{2} \mathrm{SO}_{4}$, filtered, and concentrated in vacuo to give $25 \mathrm{~b}$ (24 $\mathrm{mg}, 80.7 \%)$ as yellow solid.

(E)-3-((2-(2,2-diphenylbenzo[d][1,3]dioxol-5-yl)-5-hydroxy-4-oxo-4H-chromen-7-yl)oxy)propyl 3-(4-acetoxyphenyl)acrylate (26a): Compound 26a (34 $\mathrm{mg}, 24.4 \%$ ) was synthesized from 25a (101 $\mathrm{mg}, 0.2 \mathrm{mmol}$ ) according to the procedure used to prepare 17. The crude product was purified by column chromatography (PE/acetone $=5: 1)$ to give $\mathbf{2 6 a}$ as yellow solids.

(E)-4-((2-(2,2-diphenylbenzo[d][1,3]dioxol-5-yl)-5-hydroxy-4-oxo-4H-chromen-7-yl)oxy)butyl 3-(4-acetoxyphenyl)acrylate (26b): Compound $\mathbf{2 6 b}(19 \mathrm{mg}, 58.1 \%)$ was synthesized from $25 \mathrm{~b}$ ( $24 \mathrm{mg}, 0.046 \mathrm{mmol}$ ) according to the procedure used to prepare 17. The crude product was purified by column chromatography $(\mathrm{PE} / \mathrm{DCM} /$ acetone $=10: 10: 1)$ to give $\mathbf{2 5} \mathbf{b}$ as yellow solids.

(E)-5-((2-(2,2-diphenylbenzo[d][1,3]dioxol-5-yl)-5-hydroxy-4-oxo-4H-chromen-7-yl)oxy)pentyl 3-(4-acetoxyphenyl)acrylate (26c): Compound 26c (17 mg, 36.1\%) was synthesized from 25c ( $35 \mathrm{mg}, 0.065 \mathrm{mmol}$ ) according to the procedure used to prepare 17. The crude product was purified by column chromatography $(\mathrm{PE} / \mathrm{DCM} /$ acetone $=10: 10: 1)$ to give $\mathbf{2 6}$ c as yellow solids.

(E)-6-((2-(2,2-diphenylbenzo[d][1,3]dioxol-5-yl)-5-hydroxy-4-oxo-4H-chromen-7-yl)oxy)hexyl 3-(4-acetoxyphenyl)acrylate (26d): Compound $\mathbf{2 6 d}$ (35 $\mathrm{mg}, 33.8 \%$ ) was synthesized from 25d (75 $\mathrm{mg}, 0.14 \mathrm{mmol}$ ) according to the procedure used to prepare 17 . The crude product was purified by column chromatography $(\mathrm{PE} / \mathrm{DCM} /$ acetone $=10: 10: 1)$ to give $\mathbf{2 6 \mathbf { d }}$ as yellow solids.

(E)-8-((2-(2,2-diphenylbenzo[d][1,3]dioxol-5-yl)-5-hydroxy-4-oxo-4H-chromen-7-yl)oxy)octyl 3-(4-acetoxyphenyl)acrylate (26e): Compound 26e (52 $\mathrm{mg}, 40.1 \%$ ) was synthesized from 25e (100 $\mathrm{mg}, 0.17 \mathrm{mmol}$ ) according to the procedure used to prepare 17. The crude product was purified by column chromatography $(\mathrm{PE} / \mathrm{DCM} / \mathrm{THF}=20: 20: 3)$ to give 26e as yellow solids.

(E)-10-((2-(2,2-diphenylbenzo[d][1,3]dioxol-5-yl)-5-hydroxy-4-oxo-4H-chromen-7-yl)oxy)decyl

3-(4-acetoxyphenyl)acrylate (26f): Compound $26 \mathrm{f}$ (44 $\mathrm{mg}, 30.7 \%$ ) was synthesized from $25 \mathbf{f}$ $(110 \mathrm{mg}, 0.18 \mathrm{mmol}$ ) according to the procedure used to prepare 17. The crude product was purified by column chromatography $(\mathrm{PE} / \mathrm{DCM} / \mathrm{THF}=20: 20: 3)$ to give $\mathbf{2 6 f}$ as yellow solids.

(E)-3-((2-(3,4-dihydroxyphenyl)-5-hydroxy-4-oxo-4H-chromen-7-yl)oxy)propyl 3-(4-hydroxyphenyl)acrylate (5a): Compound 5a (12 mg, 48.9\%) was synthesized from 26a (34 mg, $0.05 \mathrm{mmol})$ according to 
the procedure used to prepare $\mathbf{4 j}$. The crude product was purified by column chromatography (chloroform/methanol $=35: 1$ ) to give $\mathbf{5 a}$ as yellow solids.

(E)-4-((2-(3,4-dihydroxyphenyl)-5-hydroxy-4-oxo-4H-chromen-7-yl)oxy)butyl 3-(4-hydroxyphenyl)acrylate (5b): Compound $\mathbf{5 b}(5.2 \mathrm{mg}, 36.8 \%)$ was synthesized from $\mathbf{2 6 \mathbf { b }}(19 \mathrm{mg}, 0.028 \mathrm{mmol})$, according to the procedure used to prepare $\mathbf{5 a}$, to give $\mathbf{5 b}$ as yellow solids.

(E)-5-((2-(3,4-dihydroxyphenyl)-5-hydroxy-4-oxo-4H-chromen-7-yl)oxy)pentyl 3-(4-hydroxyphenyl)acrylate, (5c): Compound 5c (5.1 mg, 42.8\%) was synthesized from $26 \mathrm{c}(17 \mathrm{mg}, 0.023 \mathrm{mmol})$, according to the procedure used to prepare $\mathbf{5 a}$, to give $\mathbf{5 c}$ as yellow solids.

(E)-6-((2-(3,4-dihydroxyphenyl)-5-hydroxy-4-oxo-4H-chromen-7-yl)oxy)hexyl 3-(4-hydroxyphenyl)acrylate (5d): Compound $5 \mathrm{~d}(6.9 \mathrm{mg}, 27.6 \%)$ was synthesized from $26 \mathrm{~d}(35 \mathrm{mg}, 0.047 \mathrm{mmol})$, according to the procedure used to prepare $\mathbf{5 a}$, to give $\mathbf{5 d}$ as yellow solids.

(E)-8-((2-(3,4-dihydroxyphenyl)-5-hydroxy-4-oxo-4H-chromen-7-yl)oxy)octyl 3-(4-hydroxyphenyl)acrylate (5e): Compound $5 \mathbf{e}(8.2 \mathrm{mg}, 29.3 \%)$ was synthesized from $\mathbf{2 6 e}(38 \mathrm{mg}, 0.05 \mathrm{mmol})$, according to the procedure used to prepare $\mathbf{5 a}$, to give $\mathbf{5 e}$ as yellow solids.

(E)-10-((2-(3,4-dihydroxyphenyl)-5-hydroxy-4-oxo-4H-chromen-7-yl)oxy)decyl 3-(4-hydroxyphenyl)acrylate (5f): Compound $\mathbf{5 f}(7.3 \mathrm{mg}, 27.6 \%)$ was synthesized from $26 \mathrm{f}(36 \mathrm{mg}, 0.045 \mathrm{mmol})$, according to the procedure used to prepare $\mathbf{5 a}$, to give $\mathbf{5} \mathbf{f}$ as yellow solids.

\subsubsection{Synthesis of Compound $7 \mathbf{a}-\mathbf{q}$}

2-(2,2-diphenylbenzo[d][1,3]dioxol-5-yl)-5-hydroxy-7-(2-hydroxyethoxy)-4H-chromen-4-one (27): Compound $27(195 \mathrm{mg}, 57 \%)$ was synthesized from 23 according to the procedure used to prepare 25a. The crude product was purified by column chromatography $\left(\mathrm{CH}_{2} \mathrm{Cl}_{2} /\right.$ acetone $\left.=10: 1\right)$ to give 27 as yellow solids.

2-((2-(2,2-diphenylbenzo[d][1,3]dioxol-5-yl)-5-hydroxy-4-oxo-4H-chromen-7-yl)oxy)ethyl cinnamate (28a): Compound 28a ( $28 \mathrm{mg}, 57.6 \%$ ) was synthesized from $27(40 \mathrm{mg}, 0.08 \mathrm{mmol})$ and cinnamic acid ( $35 \mathrm{mg}$, $0.24 \mathrm{mmol}$ ) according to the procedure used to prepare 21. The crude product was purified by column chromatography (PE/acetone $=5: 1)$ to give $\mathbf{2 8 a}$ as yellow solids.

(E)-2-((2-(2,2-diphenylbenzo[d][1,3]dioxol-5-yl)-5-hydroxy-4-oxo-4H-chromen-7-yl)oxy)ethyl

3-(2-acetoxyphenyl)acrylate (28b): To a solution of 2-acetoxycinnamic acid (54 mg, $0.26 \mathrm{mmol}$ ) in dichloroethane $(5 \mathrm{~mL}), \mathrm{SOCl}_{2}(100 \mu \mathrm{L}, 2.6 \mathrm{mmol})$ and DMF (1d) were added. The solution was stirred at $80^{\circ} \mathrm{C}$ for $1 \mathrm{~h}$, the organic solvent was removed under vacuum, and the residue dissolved in dry $\mathrm{CH}_{2} \mathrm{Cl}_{2}(4 \mathrm{~mL})$. Pyridine $(31 \mu \mathrm{L}, 0.38 \mathrm{mmol})$ was added at $0{ }^{\circ} \mathrm{C}$, then $27(64 \mathrm{mg}, 0.13 \mathrm{mmol})$ was added dropwise. The resulting mixture was transferred to r.t. and stirred for $4 \mathrm{~h}$. The organic solvent was washed with $1 \mathrm{M}$ hydrochloric acid and brine, dried over $\mathrm{Na}_{2} \mathrm{SO}_{4}$, filtered, and concentrated in vacuo. The crude product was purified by column chromatography (PE/acetone $=5: 1$ ) to give $\mathbf{2 8 b}$ as yellow solid (58 mg, 50.3\%).

(E)-2-((2-(2,2-diphenylbenzo[d][1,3]dioxol-5-yl)-5-hydroxy-4-oxo-4H-chromen-7-yl)oxy)ethyl

3-(3-acetoxyphenyl)acrylate (28c): Compound 28c (48 mg, 35.2\%) was synthesized from 27 (100 $\mathrm{mg}, 0.2 \mathrm{mmol})$ and 3-acetoxycinnamic acid $(124 \mathrm{mg}, 0.6 \mathrm{mmol})$, according to the procedure used to prepare $\mathbf{2 1}$. The crude product was purified by column chromatography ( $\mathrm{PE} /$ acetone $=5: 1)$ to give $\mathbf{2 8 c}$ as yellow solids.

(E)-4-(3-(2-((2-(2,2-diphenylbenzo[d][1,3]dioxol-5-yl)-5-hydroxy-4-oxo-4H-chromen-7-yl)oxy)ethoxy)-3-oxoprop -1-en-1-yl)-1,2-phenylene diacetate (28d): Compound $\mathbf{2 8 d}$ ( $24 \mathrm{mg}, 46.3 \%)$ was synthesized from 27 (35 mg, $0.07 \mathrm{mmol})$ and 3,4-diacetoxycinnamic acid $(28 \mathrm{mg}, 0.11 \mathrm{mmol})$, according to the procedure used to prepare $\mathbf{2 8 \mathbf { b }}$. The crude product was purified by column chromatography (PE/acetone $=4: 1)$ to give $28 \mathrm{~d}$ as yellow solids. 
(E)-2-((2-(2,2-diphenylbenzo[d][1,3]dioxol-5-yl)-5-hydroxy-4-oxo-4H-chromen-7-yl)oxy)ethyl

3-(4-fluorophenyl)acrylate (28e): Compound $28 \mathrm{e}(37 \mathrm{mg}, 44.3 \%)$ was synthesized from 27 (64 mg, $0.13 \mathrm{mmol}$ ) and 4-fluorocinnamic acid $(65 \mathrm{mg}, 0.39 \mathrm{mmol})$, according to the procedure used to prepare 21. The crude product was purified by column chromatography (PE/acetone $=5: 1)$ to give $28 \mathbf{e}$ as white solids.

(E)-2-((2-(2,2-diphenylbenzo[d][1,3]dioxol-5-yl)-5-hydroxy-4-oxo-4H-chromen-7-yl)oxy)ethyl

3-(4-chlorophenyl)acrylate (28f): Compound $28 \mathrm{f}(44 \mathrm{mg}, 55.6 \%)$ was synthesized from $27(60 \mathrm{mg}$, $0.12 \mathrm{mmol})$ and 4-chlorocinnamic acid $(66 \mathrm{mg}, 0.36 \mathrm{mmol})$, according to the procedure used to prepare 21. The crude product was purified by column chromatography ( $\mathrm{PE} /$ acetone $=5: 1$ ) to give $\mathbf{2 8 f}$ as yellow solids.

(E)-2-((2-(2,2-diphenylbenzo[d][1,3]dioxol-5-yl)-5-hydroxy-4-oxo-4H-chromen-7-yl)oxy)ethyl

3-(4-nitrophenyl)acrylate (28g): Compound $28 \mathrm{~g}$ (34 $\mathrm{mg}, 55.8 \%)$ was synthesized from 27 (45 mg, $0.09 \mathrm{mmol}$ ) and 4-nitrocinnamic acid ( $52 \mathrm{mg}, 0.27 \mathrm{mmol})$, according to the procedure used to prepare 21. The crude product was purified by column chromatography (PE/acetone $=5: 1$ ) to give $28 \mathrm{~g}$ as white solids.

(E)-2-((2-(2,2-diphenylbenzo[d][1,3]dioxol-5-yl)-5-hydroxy-4-oxo-4H-chromen-7-yl)oxy)ethyl

3-(4-(dimethylamino)phenyl)acrylate (28h): Compound $\mathbf{2 8 h}(24 \mathrm{mg}, 45.1 \%)$ was synthesized from 27 ( $40 \mathrm{mg}, 0.08 \mathrm{mmol}$ ) and 4-dimethylaminocinnamic acid ( $46 \mathrm{mg}, 0.24 \mathrm{mmol})$, according to the procedure used to prepare 21 . The crude product was purified by column chromatography (PE/acetone $=5: 1)$ to give $28 \mathrm{~h}$ as white solids.

(E)-2-((2-(2,2-diphenylbenzo[d][1,3]dioxol-5-yl)-5-hydroxy-4-oxo-4H-chromen-7-yl)oxy)ethyl

3-(4-methoxyphenyl)acrylate (28i): Compound $28 \mathbf{i}(44 \mathrm{mg}, 42.1 \%$ ) was synthesized from 27 $(80 \mathrm{mg}, 0.16 \mathrm{mmol})$ and 4-methoxycinnamic acid $(86 \mathrm{mg}, 0.48 \mathrm{mmol})$, according to the procedure used to prepare 21. The crude product was purified by column chromatography (PE/acetone $=5: 1$ ) to give $28 \mathrm{i}$ as yellow solids.

(E)-2-((2-(2,2-diphenylbenzo[d][1,3]dioxol-5-yl)-5-hydroxy-4-oxo-4H-chromen-7-yl)oxy)ethyl 3-(4-(tert-butyl) phenyl)acrylate (28j): Compound $\mathbf{2 8 \mathbf { j }}(31 \mathrm{mg}, 48.4 \%)$ was synthesized from $27(51 \mathrm{mg}, 0.1 \mathrm{mmol}$ ) and 4-tert-butylcinnamic acid (61 mg, $0.3 \mathrm{mmol})$, according to the procedure used to prepare 21 . The crude product was purified by column chromatography (PE/acetone $=5: 1)$ to give $\mathbf{2 8} \mathbf{j}$ as white solids.

(E)-2-((2-(2,2-diphenylbenzo[d][1,3]dioxol-5-yl)-5-hydroxy-4-oxo-4H-chromen-7-yl)oxy)ethyl 3-(pyridin-3-yl) acrylate (28k): Compound 28k (63 mg, 63.0\%) was synthesized from $27(80 \mathrm{mg}, 0.16 \mathrm{mmol})$ and (E)-3-(pyridin-3-yl)acrylic acid ( $46 \mathrm{mg}, 0.48 \mathrm{mmol}$ ), according to the procedure used to prepare 21 . The crude product was purified by column chromatography (PE/acetone $=3: 1)$ to give $\mathbf{2 8 k}$ as yellow solids.

(E)-2-((2-(2,2-diphenylbenzo[d][1,3]dioxol-5-yl)-5-hydroxy-4-oxo-4H-chromen-7-yl)oxy)ethyl 3-(furan-3-yl) acrylate (281): Compound 281 (36 mg, 36.6\%) was synthesized from $27(80 \mathrm{mg}, 0.16 \mathrm{mmol})$ and (E)-3-(furan-3-yl)acrylic acid ( $66 \mathrm{mg}, 0.48 \mathrm{mmol}$ ), according to the procedure used to prepare 21 . The crude product was purified by column chromatography ( $\mathrm{PE} /$ acetone $=5: 1)$ to give $\mathbf{2 8 1}$ as white solids.

(E)-2-((2-(2,2-diphenylbenzo[d][1,3]dioxol-5-yl)-5-hydroxy-4-oxo-4H-chromen-7-yl)oxy)ethyl

3-cyclohexylacrylate (28m): Compound $28 \mathrm{~m}$ ( $43 \mathrm{mg}, 42.7 \%)$ was synthesized from 27 (80 $\mathrm{mg}$, $0.16 \mathrm{mmol}$ ) and (E)-3-cyclohexylacrylic acid $(74 \mathrm{mg}, 0.48 \mathrm{mmol})$, according to the procedure used to prepare 21. The crude product was purified by column chromatography $(\mathrm{PE} / \mathrm{DCM} /$ acetone $=20: 20: 1)$ to give $\mathbf{2 8} \mathrm{m}$ as yellow solids.

(E)-2-((2-(2,2-diphenylbenzo[d][1,3]dioxol-5-yl)-5-hydroxy-4-oxo-4H-chromen-7-yl)oxy)ethyl 3-(3,5-dimethyl -1H-pyrazol-1-yl)acrylate (28n): Compound 28n (42 mg, 81.6\%) was synthesized from 27 (41 mg, 0.08 $\mathrm{mmol}$ ) and 3-(3,5-dimethyl-1H-pyrazol-1-yl)propanoic acid (41 mg, $0.24 \mathrm{mmol})$, according to the 
procedure used to prepare 21 . The crude product was purified by column chromatography (PE/acetone $=4: 1$ ) to give $28 \mathrm{~m}$ as yellow solids.

2-((2-(2,2-diphenylbenzo[d][1,3]dioxol-5-yl)-5-hydroxy-4-oxo-4H-chromen-7-yl)oxy)ethyl 4-acetoxybenzoate (280): Compound 280 ( $24 \mathrm{mg}, 53.7 \%)$ was synthesized from $27(31 \mathrm{mg}, 0.07 \mathrm{mmol})$ and 4-hydroxybenzoic acid $(29 \mathrm{mg}, 0.21 \mathrm{mmol})$, according to the procedure used to prepare $28 \mathbf{b}$. The crude product was purified by column chromatography (PE/acetone $=5: 1$ ) to give 280 as yellow solids.

(E)-2-(2-(2,2-diphenylbenzo[d][1,3]dioxol-5-yl)-5-hydroxy-4-oxo-4H-chromen-7-yloxy)ethyl

3-(4-acetoxyphenyl)acrylate (28q): Compound $\mathbf{2 8 q}$ (76 mg, 55.7\%) was synthesized from 27 (100 mg, $0.2 \mathrm{mmol}$ ) and 4-acetoxycinnamic acid (124 mg, $0.6 \mathrm{mmol})$, according to the procedure used to prepare 21 . The crude product was purified by column chromatography (PE/acetone $=5: 1)$ to give $\mathbf{2 8 q}$ as yellow solids.

2-((2-(3,4-dihydroxyphenyl)-5-hydroxy-4-oxo-4H-chromen-7-yl)oxy)ethyl cinnamate (7a): $28 \mathbf{a}$ (9 mg, $0.015 \mathrm{mmol})$ was dissolved in a solution of acetone $(0.1 \mathrm{~mL})$ and $38 \% \mathrm{HCl} / \mathrm{AcOH}(v / v=1: 15,0.5 \mathrm{~mL})$. The mixture was stirred at room temperature for $20 \mathrm{~h}$. Th resulting mixture was poured into ice-water and extracted with EtOAc. The organic layer was washed with brine, dried over anhydrous $\mathrm{Na}_{2} \mathrm{SO}_{4}$, and concentrated in vacuo. The residue was purified by column chromatography ( $\mathrm{DCM} / \mathrm{MeOH}=50: 1)$ to give $7 \mathbf{a}$ as yellow solid $(2.4 \mathrm{mg}, 32.6 \%)$.

(E)-2-((2-(3,4-dihydroxyphenyl)-5-hydroxy-4-oxo-4H-chromen-7-yl)oxy)ethyl 3-(2-acetoxyphenyl)acrylate (7b): Compound $\mathbf{7 b}$ ( $26.7 \mathrm{mg}, 75.8 \%$ ) was synthesized from $\mathbf{2 8 b}(49 \mathrm{mg}, 0.072 \mathrm{mmol}$ ) according to the procedure used to prepare $\mathbf{7 a}$, obtained as brown solids.

(E)-2-((2-(3,4-dihydroxyphenyl)-5-hydroxy-4-oxo-4H-chromen-7-yl)oxy)ethyl 3-(3-acetoxyphenyl)acrylate (7c): Compound 7c (12.8 mg, 45.6\%) was synthesized from $28 \mathrm{c}(40 \mathrm{mg}, 0.059 \mathrm{mmol})$ according to the procedure used to prepare $7 \mathrm{a}$, obtained as yellow solids.

(E)-4-(3-(2-((2-(3,4-dihydroxyphenyl)-5-hydroxy-4-oxo-4H-chromen-7-yl)oxy)ethoxy)-3-oxoprop-1-en-1-yl)-1,2 -phenylene diacetate $(7 \mathrm{~d})$ : Compound $7 \mathbf{d}(2.2 \mathrm{mg}, 37.3 \%)$ was synthesized from $\mathbf{2 8 d}(6 \mathrm{mg}, 0.012$ $\mathrm{mmol}$ ), according to the procedure used to prepare $7 \mathrm{a}$. The crude product was purified by column chromatography $(\mathrm{DCM} / \mathrm{MeOH}=20: 1)$ to give $\mathbf{7} \mathbf{d}$ as white solids.

(E)-2-((2-(3,4-dihydroxyphenyl)-5-hydroxy-4-oxo-4H-chromen-7-yl)oxy)ethyl 3-(4-fluorophenyl)acrylate (7e): Compound $7 \mathbf{e}(9.3 \mathrm{mg}, 62.7 \%)$ was synthesized from $28 \mathbf{e}(23 \mathrm{mg}, 0.031 \mathrm{mmol})$ according to the procedure used to prepare $7 \mathbf{a}$, obtained as light-yellow solids.

(E)-2-((2-(3,4-dihydroxyphenyl)-5-hydroxy-4-oxo-4H-chromen-7-yl)oxy)ethyl 3-(4-chlorophenyl)acrylate (7f): Compound $\mathbf{7 f}$ ( $26 \mathrm{mg}, 87.7 \%$ ) was synthesized from $\mathbf{2 8 f}(40 \mathrm{mg}, 0.06 \mathrm{mmol})$ according to the procedure used to prepare $7 \mathbf{a}$ without post process, obtained as white solids.

(E)-2-((2-(3,4-dihydroxyphenyl)-5-hydroxy-4-oxo-4H-chromen-7-yl)oxy)ethyl 3-(4-nitrophenyl)acrylate (7g): Compound $7 \mathrm{~g}(4.1 \mathrm{mg}, 63.5 \%)$ was synthesized from $28 \mathrm{~g}(9 \mathrm{mg}, 0.013 \mathrm{mmol})$ according to the procedure used to prepare $7 \mathbf{a}$, obtained as white solids.

(E)-2-((2-(3,4-dihydroxyphenyl)-5-hydroxy-4-oxo-4H-chromen-7-yl)oxy)ethyl 3-(4-(dimethylamino)phenyl) acrylate (7h): Compound $\mathbf{7 h}(5.1 \mathrm{mg}, 49.7 \%)$ was synthesized from $\mathbf{2 8 h}(15 \mathrm{mg}, 0.02 \mathrm{mmol})$ according to the procedure used to prepare $7 \mathbf{a}$, obtained as yellow solids.

(E)-2-((2-(3,4-dihydroxyphenyl)-5-hydroxy-4-oxo-4H-chromen-7-yl)oxy)ethyl 3-(4-methoxyphenyl)acrylate (7i): Compound $7 \mathbf{i}(18.8 \mathrm{mg}, 57.3 \%)$ was synthesized from $28 \mathbf{i}(44 \mathrm{mg}, 0.067 \mathrm{mmol})$ according to the procedure used to prepare $7 \mathbf{a}$, obtained as white solids

(E)-2-((2-(3,4-dihydroxyphenyl)-5-hydroxy-4-oxo-4H-chromen-7-yl)oxy)ethyl 3-(4-(tert-butyl)phenyl)acrylate (7j): Compound $7 \mathbf{j}(8.8 \mathrm{mg}, 46.3 \%)$ was synthesized from $28 \mathbf{j}(25 \mathrm{mg}, 0.037 \mathrm{mmol})$ according to the procedure used to prepare $7 \mathbf{a}$, obtained as white solids. 
(E)-2-((2-(3,4-dihydroxyphenyl)-5-hydroxy-4-oxo-4H-chromen-7-yl)oxy)ethyl 3-(pyridin-3-yl)acrylate (7k): Compound $7 \mathbf{k}(12 \mathrm{mg}, 57.3 \%)$ was synthesized from $\mathbf{2 8 k}(20 \mathrm{mg}, 0.067 \mathrm{mmol})$ according to the procedure used to prepare $7 \mathbf{a}$, obtained as yellow solids.

(E)-2-((2-(3,4-dihydroxyphenyl)-5-hydroxy-4-oxo-4H-chromen-7-yl)oxy)ethyl 3-(furan-3-yl)acrylate (71): Compound $71(4.4 \mathrm{mg}, 42.5 \%)$ was synthesized from 281 (14 mg, $0.023 \mathrm{mmol})$ according to the procedure used to prepare $\mathbf{7 a}$, obtained as light-yellow solids.

(E)-2-((2-(3,4-dihydroxyphenyl)-5-hydroxy-4-oxo-4H-chromen-7-yl)oxy)ethyl 3-cyclohexylacrylate (7m): Compound $7 \mathrm{~m}(19.2 \mathrm{mg}, 60.6 \%)$ was synthesized from $28 \mathrm{~m}(43 \mathrm{mg}, 0.068 \mathrm{mmol})$ according to the procedure used to prepare $\mathbf{7 a}$, obtained as white solids.

(E)-2-((2-(3,4-dihydroxyphenyl)-5-hydroxy-4-oxo-4H-chromen-7-yl)oxy)ethyl 3-(3,5-dimethyl-1H-pyrazol-1yl)acrylate (7n): Compound $\mathbf{7 n}(14.2 \mathrm{mg}, 59.2 \%)$ was synthesized from $\mathbf{2 8 n}$ (32 mg, $0.05 \mathrm{mmol})$ according to the procedure used to prepare $7 \mathbf{a}$, obtained as yellow solids.

2-((2-(3,4-dihydroxyphenyl)-5-hydroxy-4-oxo-4H-chromen-7-yl)oxy)ethyl 4-hydroxybenzoate (7o): Compound $7 \mathbf{o}(5.2 \mathrm{mg}, 57.8 \%)$ was synthesized from $28 \mathrm{o}(12 \mathrm{mg}, 0.02 \mathrm{mmol})$ according to the procedure used to prepare 7 a, obtained as yellow solids.

2-((2-(3,4-dihydroxyphenyl)-5-hydroxy-4-oxo-4H-chromen-7-yl)oxy)ethyl 3-(4-hydroxyphenyl)propanoate (7p): To a solution of compound $28 \mathrm{p}(24 \mathrm{mg}, 0.038 \mathrm{mmol})$ in THF $(1 \mathrm{~mL})$ and $\mathrm{EtOH}(1 \mathrm{~mL}), 10 \% \mathrm{~Pb} / \mathrm{C}(16 \mathrm{mg}$, $0.015 \mathrm{mmol})$ and 1,4-cyclohexadiene $(141 \mu \mathrm{L}, 1.5 \mathrm{mmol})$ were added. The solution was stirred reflux for $5 \mathrm{~h}$. The resulting solution was concentrated after filtrating and purified by column chromatography $(\mathrm{DCM} / \mathrm{MeOH}=40: 1)$ to give $7 \mathrm{p}$ as yellow solid $(11 \mathrm{mg}, 61.4 \%)$.

(E)-2-((2-(3,4-dihydroxyphenyl)-5-hydroxy-4-oxo-4H-chromen-7-yl)oxy)ethyl 3-(4-acetoxyphenyl)acrylate (7q): To a solution of compound $\mathbf{2 8 q}$ (100 mg, $0.15 \mathrm{mmol})$ in DCM (5 mL), $\mathrm{CF}_{3} \mathrm{COOH}(0.55 \mathrm{~mL}, 7.5 \mathrm{mmol})$ was added. The solution was stirred at room temperature for $12 \mathrm{~h}$. The resulting solution was concentrated and purified by column chromatography $(\mathrm{DCM} / \mathrm{MeOH}=30: 1)$ to give $7 \mathrm{q}$ as yellow solid $(16.7 \mathrm{mg}$, $31.4 \%$ ).

\subsection{In Vitro BACE1 Enzyme Assay}

The BACE1 FRET assay kit was purchased from the PanVera Co. (Invitrogen, USA). The assay was carried out according to the supplied manual with modifications. Briefly, assays were performed in triplicate in 384-well black plates with a mixture of $5 \mu \mathrm{L}$ of BACE1 $(1.0 \mathrm{U} / \mathrm{mL}), 5 \mu \mathrm{L}$ of the substrate (750 nM, Rh-EVNLDAEFK-Quencherin $50 \mathrm{mM}$, ammonium bicarbonate), and $5 \mu \mathrm{L}$ of compound dissolved in $10 \%$ DMSO. The fluorescence intensity was measured with a TECAN infinite 200 microplate reader for $60 \mathrm{~min}$ at $25^{\circ} \mathrm{C}$ in the dark. The mixture was irradiated at $544 \mathrm{~nm}$ and the emission intensity recorded at $590 \mathrm{~nm}$. The percent inhibition (\%) was obtained by the following equation: Inhibition $\%=$ $(1-\mathrm{SS} / \mathrm{SC}) \times 100 \%$, where SC is the slope of fluorescence change of the control (enzyme, buffer, and substrate) during $60 \mathrm{~min}$, and SS is the slope of fluorescence change of the tested samples (enzyme, sample solution, and substrate) during $60 \mathrm{~min}$ of measurement. $\mathrm{IC}_{50}$ values were calculated from the nonlinear curve fitting of percentage inhibition against inhibitor concentration using Prism 3.0 software (GraphPad Software, San Diego, CA, USA).

\subsection{Inhibition of A $\beta$ Production in APP Overexpressed Cells}

HEK293 cells stably overexpressing human APP695 were plated in a poly-D-lysine-coated 96-well plates and grown to a density of $80-90 \%$. Compounds were dissolved in DMSO to make a $10 \mathrm{mM}$ stock solution and diluted in DMEM complete medium to the final concentrations: 0.1, 1.0, 5.0, 10.0, 25.0, and 50.0 $\mu \mathrm{M}$. DMSO was used at a 1:200 dilution as a negative control and commercially available BACE1 inhibitor (C3, also known as BACE inhibitor IV) as a positive control. After $23 \mathrm{~h}$ of incubation, the cell supernatants were directly used for measurement in the V-Plex A $\beta$ Peptide Panel 1 (6E10) Kit 
from Meso Scale Diagnostics (Rockville, MD, USA) for measuring A $\beta 38,-40$, and -42 simultaneously. Cells were washed with PBS and lysed in Triton X100 lysis buffer for subsequent protein concentration (BCA) measurement.

\subsection{Kinetic Analysis}

The Dixon plot is a graphical method (plot of 1/enzyme velocity $(1 / \mathrm{V})$ against inhibitor concentration (I)) for determination of the type of enzyme inhibition, which was used to determine the dissociation or inhibition constant (Ki) for the enzyme inhibitor complex [17]. The Dixon plots for BACE1 inhibition were obtained in the presence of various concentrations of BACE1 substrate $(250,500,750 \mathrm{nM})$ and the concentrations of $4 \mathbf{1}, 7 \mathbf{c}$, and $7 \mathbf{k}$ as follows: $0.1 \mu \mathrm{M}, 0.5 \mu \mathrm{M}, 1.0 \mu \mathrm{M}$. In this way, the inhibition constants (Ki) of $4 \mathbf{e}$ were determined by interpretation of Dixon plots, where the value of the $x$-axis represents $-\mathrm{Ki}$ when $1 / \mathrm{V}=0$.

\subsection{MTT Assays}

The cytotoxicity was examined by using 3-[4,5-dimethylthiazol-2-yl]-2,5-diphenyl-tetrazolium bromide (MTT) assay. HEK293T cells were seeded with complete DMEM into 96-well plates (104/well, $100 \mathrm{~L} /$ well), incubated at $37^{\circ} \mathrm{C}$ in a humidified atmosphere with $5 \% \mathrm{CO}_{2}$ for $24 \mathrm{~h}$. All the compounds were diluted with the phenol red-free DMEM at a specific concentration. After $24 \mathrm{~h}$ of exposure to different concentrations of compound, the supernatant was removed and then $20 \%(v / v) \mathrm{MTT}(5 \mathrm{mg} / \mathrm{mL})$ diluted with fresh culture medium was added into each well and incubated for $4 \mathrm{~h}$. Cells were lysed with $100 \mu \mathrm{L}$ dimethyl sulfoxide (DMSO) and shaken for $10 \mathrm{~min}$ at room temperature. The absorbance in each well was detected at a wavelength of $490 \mathrm{~nm}$ using a Universal Microplate Reader (ELX $800 \mathrm{lv}$, BIO-TEK Instruments, Inc., Winooski, VT, USA).

Supplementary Materials: The following are available online at http://www.mdpi.com/1420-3049/25/1/102/s1: Scheme S1. Synthesis of compound $\mathbf{4 a - 4 h}$; Scheme S2. Synthesis of compound $4 \mathrm{i}$; Scheme S3. Synthesis of compound 4k; Scheme S4. Synthesis of compound 41; Scheme S5. Synthesis of compound 5g; Scheme S6. Synthesis of compound 6; Scheme S7. Synthesis of compound 8; Figure S1. The normalized A $\beta 38$ level in APP overexpressing HEK293 cells after the treatment of 7a-7d, 7i, 7k, and luteolin compared with DMSO (100\%) the known inhibitor C3; Figure S2 The normalized A 338 level in APP overexpressing HEK293 cells after the treatment of 7a-7d, 7i, 7k, and luteolin compared with DMSO (100\%) and the known inhibitor C3; Figure S3 Kinetic analysis of $4 \mathbf{l}$; Figure S4 Kinetic analysis of $\mathbf{7 k}$; Figure S5. S-curve for $\mathrm{IC}_{50}$ calculation of compounds $7 \mathbf{a}, 7 \mathrm{~d}, 7 \mathbf{p}, 7 \mathbf{h}, 7 \mathbf{g}, 7 \mathbf{k}$, and 8; Table S1. The NMR data and MS data of compounds shown in the text; Table S2. ClogP and BBB level calculation by http://admet.scbdd.com/

Author Contributions: D.-Y.S. performed chemical synthesis and some enzyme experiments; C.C. carried out the cytotoxicity test and enzyme selectivity test; K.M. carried out the study of enzyme inhibition activity in cells; writing — original draft preparation, D.-Y.S. and C.C.; writing—review and editing, W.-S.F. and J.H.; W.-S.F. planned, designed, and organized the whole research of this study. All authors have read and agreed to the published version of the manuscript.

Funding: This research was funded by NSFC, grant nos. 81273406 (W.-S.F.) and 31371331 (J.H.), and by the Drug Innovation Major Project Grant, grant nos. 2018ZX09711001-001-001 and 2018ZX09711001-001-003.

Acknowledgments: The authors cordially thank Stefan Lichtenthaler, Technical University of Munich for his generous support to this work.

Conflicts of Interest: The authors declare no conflict of interest regarding the publication of this paper.

\section{References}

1. Silva, T.; Reis, J.; Teixeira, J.C.S.; Borges, F. Alzheimer's disease, enzyme targets and drug discovery struggles: From natural products to drug prototypes. Ageing. Res. Rev 2014, 15, 116-145. [CrossRef] [PubMed]

2. Dourlen, P.; Kilinc, D.; Malmanche, N.; Chapuis, J.; Lambert, J.C. The new genetic landscape of Alzheimer's disease: From amyloid cascade to genetically driven synaptic failure hypothesis? Acta Neuropathol. 2019, 138, 221-236. [CrossRef] [PubMed]

3. Karran, E.; Mercken, M.; De, S.B. The amyloid cascade hypothesis for Alzheimer's disease: An appraisal for the development of therapeutics. Nat. Rev. Drug. Disc. 2011, 10, 698-712. [CrossRef] [PubMed] 
4. Cline, E.; Bicca, M.A.; Viola, K.L.; Klein, W.L. The amyloid- $\beta$ oligomer hypothesis: Beginning of the third decade. J. Alzheimers. Dis. 2018, 64, S567-S610. [CrossRef] [PubMed]

5. Vassar, R.; Kuhn, P.-H.; Haass, C.; Kennedy, M.E.; Rajendran, L.; Wong, P.C.; Lichtenthaler, S. Function, therapeutic potential and cell biology of BACE proteases: Current status and future prospects. J. Neurochem. 2014, 130, 4-28. [CrossRef] [PubMed]

6. Coimbra, J.R.M.; Marques, D.F.F.; Baptista, S.J.; Pereira, C.M.F.; Moreira, P.I.; Dinis, T.C.P.; Santos, A.E.; Salvador, J.A.R. Highlights in BACE1 inhibitors for Alzheimer's disease treatment. Front. Chem. 2018, 6, 178-188. [CrossRef] [PubMed]

7. Weller, J.; Budson, A. Current understanding of Alzheimer's disease diagnosis and treatment. F1000Research 2018, 7, 1161-1170. [CrossRef] [PubMed]

8. Hu, X.; Das, B.; Hou, H.; He, W.; Yan, R. BACE1 deletion in the adult mouse reverses preformed amyloid deposition and improves cognitive functions. J. Exp. Med. 2018, 3, 927-940. [CrossRef] [PubMed]

9. Keskin, A.D.; Kekuš, M.; Adelsberger, H.; Neumann, U.; Shimshek, D.R.; Song, B.; Zott, B.; Peng, T.; Förstl, H.; Staufenbiel, M.; et al. BACE inhibition-dependent repair of Alzheimer's pathophysiology. Proc. Natl. Acad. Sci. USA 2017, 114, 8631-8636. [CrossRef] [PubMed]

10. Justyna, A.; Zakaria, J.A.D.; Vassar, R.J. A promising, novel, and unique BACE1 inhibitor emerges in the quest to prevent Alzheimer's disease. EMBO Mol. Med. 2018, 10, 1-3.

11. Morris, G.P.; Clark, I.A.; Vissel, B. Questions concerning the role of amyloid- $\beta$ in the definition, aetiology and diagnosis of Alzheimer's disease. Acta. Neuropathol. 2018, 136, 663-689. [CrossRef] [PubMed]

12. Williams, P.; Sorribas, A.; Howes, M.J. Natural products as a source of Alzheimer's drug leads. Nat. Prod. Rep. 2010, 28, 48-77. [CrossRef] [PubMed]

13. Fang, W.-S.; Sun, D.-Y.; Yang, S.; Cheng, C.; Moschke, K.; Li, T.Q.; Sun, S.S.; Stefan, L.; Huang, J.; Wang, Y.H. Discovery of a series of selective and cell permeable beta-secretase (BACE1) inhibitors by fragment linking with the assistance of STD-NMR. Bioorg. Chem. 2019, 92, 1-7. [CrossRef] [PubMed]

14. Krishna, N.R.; Jayalakshmi, V. Quantitative analysis of STD-NMR spectra of reversibly forming ligand-receptor complexes. Top. Curr. Chem. 2008, 273, 15-54. [PubMed]

15. Stachel, S.J.; Coburn, C.A.; Steele, T.G.; Jones, K.G.; Loutzenhiser, E.F.; Gregro, A.R. Structure-based design of potent and selective cell-permeable inhibitors of human beta-secretase (BACE-1). J. Med. Chem. 2004, 47, 6447-6450. [CrossRef] [PubMed]

16. Dong, J.; Wang, N.-N.; Yao, Z.-J.; Zhang, L.; Cheng, Y.; Ouyang, D.F.; Lu, A.-P.; Cao, D.-S. ADMETlab: A platform for systematic ADMET evaluation based on a comprehensively collected ADMET database. J. Cheminform. 2018, 10, 29-40. [CrossRef] [PubMed]

17. Cornish-Bowden, A.; Eisenthal, R. Statistical considerations in the estimation of enzyme kinetic parameters by the Direct Linear Plot and other methods. Biochem. J. 1974, 139, 721-730. [CrossRef] [PubMed]

Sample Availability: Not available.

(C) 2019 by the authors. Licensee MDPI, Basel, Switzerland. This article is an open access article distributed under the terms and conditions of the Creative Commons Attribution (CC BY) license (http://creativecommons.org/licenses/by/4.0/). 